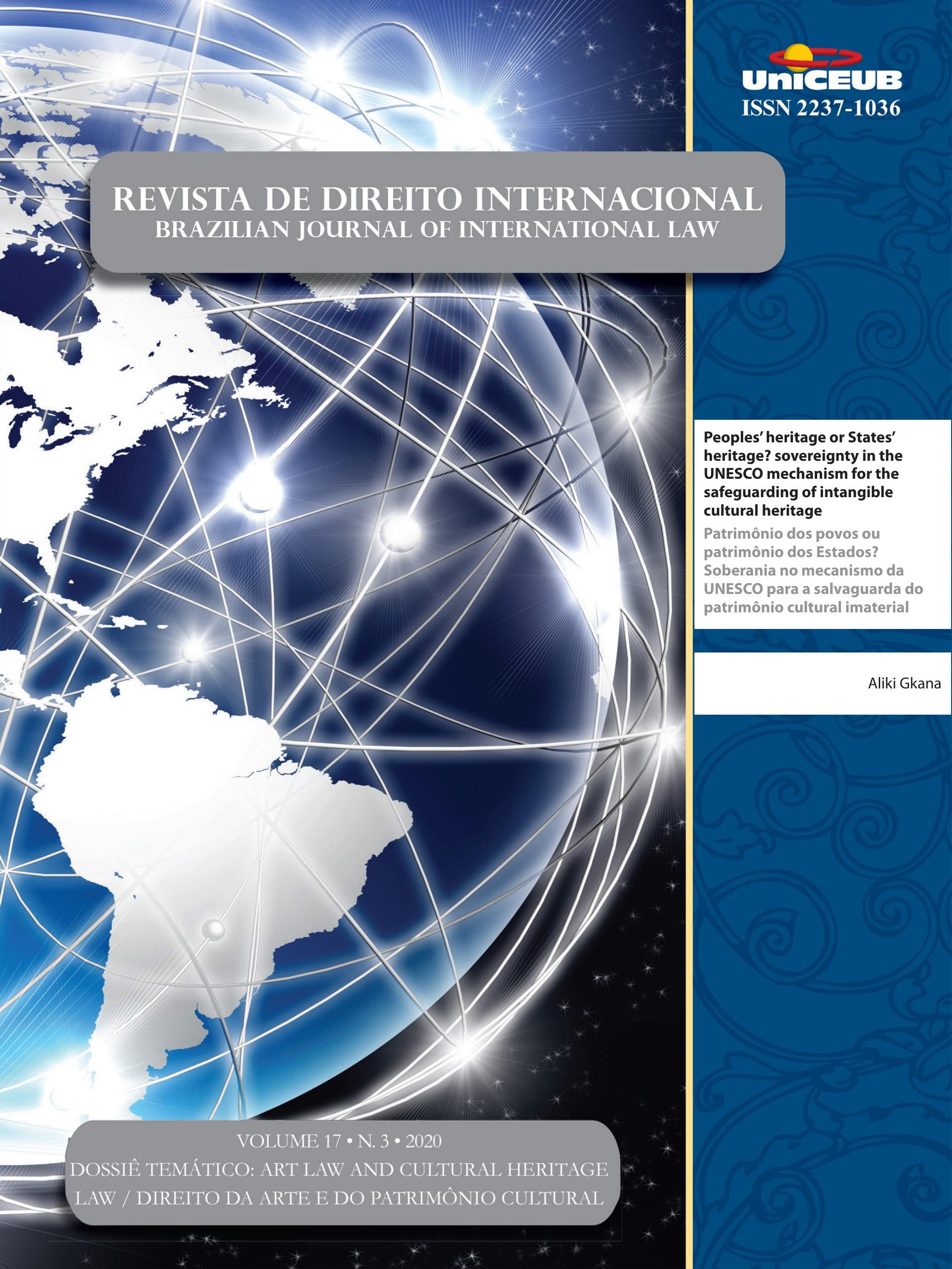




\section{Sumário}

EDITORIAL .20

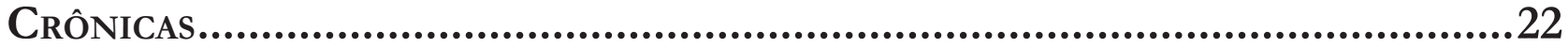

O COSTUME INTERNACIONAL COMO REFORÇO DA OBJEÇÃO BRASILEIRA À CLÁUSULA DO TRATAMENTO JUSTO E EQUITATIVO .24

Leonardo Vieira Arruda Achtschin

O PROCESSO LEGISLATIVO COMO GARANTIA PARA A OBTENÇÃo DO CONSENTIMENTO PRÉVIO DAS COMUnidades quilombolas de AlCÂNTARa

Gabriel de Oliveira Borba

Dossiê temático: Art Law and Cultural Heritage law / Direito da Arte e do Patrimônio cultural - Panorama Geral

Peoples' heritage or States' heritage? sovereignty in the UNESCO mechanism for THE SAFEGUARDING OF INTANGIBLE CULTURAL HERITAGE.

Aliki Gkana

The IMPACT OF THE UNESCO AND UNIDROIT CONVENTIONS AND THE EU DIRECTIVES ON THE INTERNATIONAL ART MARKET: AN ANALYSIS FIFTY YEARS AFTER THE INTRODUCTION OF THE OBLIGATION TO RETURN STOLEN OR ILLEGALLY EXPORTED CULTURAL GOODS 61

Geo Magri

Três pautas em destaque na agenda de diversidade Cultural da Unesco: Ambiente digiTAL, TRATAMENTO PREFERENCIAL E PARTICIPAÇÃO DA SOCIEDADE CIVIL............................76

Danilo Júnior de Oliveira, Maria Carolina Vasconcelos Oliveira e Ana Paula do Val

A 100 YEARS INSTITUTIONALIZED CULTURAL HERITAGE PROTECTION: FROM THE INSTITUTIONALIZED INTERNATIONAL COOPÉRATION INTELLECTUELLE TO THE HUMAN RIGHT TO CULTURAL HERITAGE

Lando Kirchmair 


\section{Aspectos Metodológicos do Direito da Arte e do Patrimônio}

Cultural

A proteção do PATrimônio CULTURAL EM NOVAS PERSPECTIVAS: ESTUdo COMPARAdo ENTRE A Kulturgutschutzgesetz e a Holocaust Expropriated Art Recovery Act of 2016.....111 Ardyllis Alves Soares

ArT-RELATED DispUTES AND ADR METHODS 127 Maria Beatrice Deli e Veronica Proietti

Due Diligence in Art Law and Cultural Heritage Law 150 Lisiane Feiten Wingert Ody

The Reception of Droit de Suite in International Law: Diagnosis and Remedy .... 170 Mickael R. Viglino

Direito da Arte e do Patrimônio Cultural: do Regional ao Local ....... 188

Câmara Cascudo e o legal Design - A Visualidade do Direito entre Provincianismo e GlobalizaÇão 190 Marcilio Toscano Franca Filho

A política da União Europeia no turismo: O turismo cultural e a sustentabilidade do PATRIMONNIO INDUSTRIAL PARA INTEGRAÇÃO DO BLOCO EUROPEU

Maraluce Maria Custódio e Fernando Barotti dos Santos

Diálogo entre la Corte Interamericana de Derechos Humanos y el Tribunal Europeo de Derechos Humanos en torno al Derecho humano a la identidad cultural..223 Juan Jorge Faundes

Digital ART AND THE BELT AND ROAD INITIATIVE: CHALLENGES AND OPPORTUNITIES 257 Dan Wei e Ângelo Rafael

Policing heritage crime in Latin America. .275 Naomi Oosterman e Donna Yates 
The principles of Cultural Heritage Law based on the Polish Law as an example.292 Małgorzata Joanna Węgrzak e Kamil Zeidler

Heritage Protection in INTERNATIONAL LAw AND NATIONAL LAW: INSIGHTS INTO THE CASE OF VIETNAM

Yen Thi Hong Nguyen e Dung Phuong Nguyen

THE APPROPRIATION OF THE CARIOCA INTANGIBLE CULTURAL HERITAGE BY AN ENTREPRENEURIAL LOGIC

Mário Ferreira de Pragmácio Telles

A Propósito del CARÁcter UNIVERSAL DEL aCCESO A LA CULTURA EN INTERNET: UN ANÁlisis DESDE EL PRISMA INTERNACIONAL Y LA EXPERIENCIA DEL ORDENAMIENTO JURÍDICO CUBANO 344 Janny Carrasco Medina

Direito Humanitário e Arte

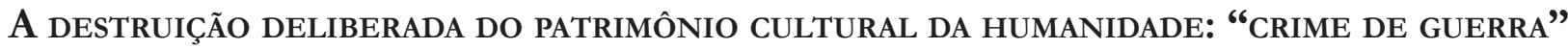
OU "CRIME CONTRA A HUMANIDADE"? Juliette Robichez

Protection OF CULTURAL PROPERTY UNDER INTERNATIONAL HUMANITARIAN LAW: EMERGING TRENDS

Niteesh Kumar Upadhyay e Mahak Rathee

Direito do Mar/Marítimo e Arte.

The underwater Cultural heritage Regime: SOME PROBlems AND POSSible SOlutions. 412 Elina Moustaira

El ROL DEL DERECHO EN LA CONSTRUCCIÓN DEL PATRIMONIO CULTURAL SUBACUÁTICO: APRECiaciones a partirdel estudio del CASo de la Corbeta Inglesa SwifT en Argentina .. 424 Norma Elizabeth Levrand e Nadia Bressan Bernhardt 
INDIGENOUS REFUGEES AND CULTURAL EROSION: POSSIBILITIES AND LIMITS OF INTERNATIONAL REFUGEE AND INDIGENOUS PEOPLES LAW IN THE PROTECTION OF INDIGENOUS CULTURAL EXPRESSIONS RELATED TO TRADITIONAL LAND AND NATIVE LANGUAGE. .440 Rickson Rios Figueira

O RETRATO DE EDMOND BELAMY E A INTERFACE ENTRE ARTE E INTELIGENCIA ARTIFICIAL: POR UMA NOVA DEFINIÇÃo DE AUTORIA E DIREITOS DE PROPRIEDADE INTELECTUAL

Marla Meneses do Amaral Leite Mangiolardo, Patrícia Silva de Almeida e Jonathan Barros Vita

Argumentative aspects of Declaration on the Importance and Value of Universal Museums (2002) 479

Agnieszka Plata

A DestinaÇão dos bens CUlturais EM PROCESSOS PENAIS: A ARTE COMO REPARAÇÃo COLETIVA 488

Inês Virgínia Prado Soares e Otavio Venturini

A Justiça de Pieter Bruegel: direito, violência e a venda nos (nossos) olhos. .501 Rafael Lazzarotto Simioni e Cícero Krupp

Artigos Sobre outros temas

DEVERES INTERNACIONAIS E OBRIGAÇÕES SOCIOAMBIENTAIS PARA EMPRESAS MULTI E TRANSNACIONAIS

Luísa Cortat Simonetti Gonçalves e Adriano Sant'Ana Pedra

Maternidade por substituição: perspectivas da ConferênCia da Haia e suas potenciais INFLUÊNCIAS NO REGRAMENTO BRASILEIRO

Tatiana de A. F. R. Cardoso Squeff e Fernanda Rezende Martins

EL (LARGO) CAMINO DE RECONOCIMIENTO Y EJECUCIÓN DE LAUDOS ARBITRALES DE INVERSIÓN

Thiago Paluma, Ivette Esis e Gabriel Briceño 
A INTERPRETAÇÃo EVOLUTIVA DA CONVENÇÃo AMERICANA SOBRE DiREITOS HUMANOS: UMA REVISÃO DOCUMENTAL DO PERÍODO 1988-2018

Breno Baía Magalhães

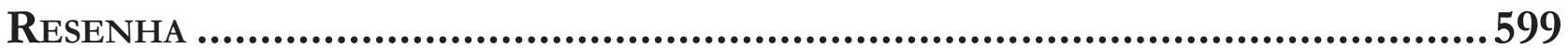

Autonomous Weapons Systems and InTERnATIONAL LAw: A STUDY ON HUMAN-MACHINE INTERACTIONS IN ETHICALLY AND LEGALLY SENSITIVE DOMAINS

Aziz Tuffi Saliba e Lutiana Valadares Fernandes Barbosa 


\title{
Peoples' heritage or States' heritage? sovereignty in the UNESCO mechanism for the safeguarding of intangible cultural heritage*
}

\author{
Patrimônio dos povos ou patrimônio dos \\ Estados? Soberania no mecanismo da \\ UNESCO para a salvaguarda do patrimônio \\ cultural imaterial
}

Aliki Gkana**

* Recebido em 30/09/2020

Aprovado em 28/02/2021

** Aliki Gkana holds an LL.B. (Honours) and an LL.M. in Public International Law (with distinction) from the National and Kapodistrian University of Athens, while she was granted an excellence award as the first in rank graduate of Law Faculty's United Programme of Postgraduate Studies for the academic year 20162017. Her research, as a $\mathrm{PhD}$ Candidate at the Faculty of Law of the University of Athens and a scholar of the Hellenic Foundation for Research and Innovation (2019-2022), the Melina Merkouri Foundation and the Sylff Association (2018-2019), focuses on the protection of intangible cultural heritage under public international law. In 2020, she worked as an intern at the Living Heritage Entity, Culture Sector at UNESCO Headquarters in Paris, partially in the context of the Erasmus + traineeship programme. Researcher of the Athens PIL Center, she has collaborated with the University of Athens as a teaching and research assistant at the LL.M. in International and European Studies (direction of Public International Law) and completed an internship at the Protection Unit of UNHCR's Athens Office in 2018. She also works as a lawyer, member of the Athens Bar Association (since 2017), while in parallel she develops manifold action in the field of intangible cultural heritage, as an executive of the "Polyphonic Caravan", an institution of Panhellenic and cross-border action devoted to the safeguarding of the Polyphonic Song and Greece's first proposal for inscription on UNESCO's International Register of Good Safeguarding Practices in the field on intangible cultural heritage. Her areas of interest are public international law, international cultural heritage law, international human rights, environmental and intellectual property law. She is fluent in Greek (native language), English, French and German.

E-mail: alikigana@gmail.com

\section{Abstract}

The paper explores the relation between State sovereignty and the safeguarding of the Intangible Cultural Heritage (hereafter ICH) pointing out the tension between a State-centered and a community-oriented approach within the existent protection mechanism. In the first part, the writer outlines the legal framework established by the 2003 UNESCO Convention, examining some of its "sovereignty guarantees". In the second part, she touches upon the particular issue of dealing with "shared ICH" within the UNESCO framework, examining possible responses to the apparent deficiencies towards its more effective safeguarding. Questioning whether ICH is an appropriate field for States to "reaffirm" their sovereignty or it intrinsically challenges the traditional concept of the sovereign State, she discusses the recognition of ICH's cross-border character and the common concern for its safeguarding, as well as the progressive establishment of a right to $\mathrm{ICH}$ and the demand for a more active role of its communities in the international safeguarding system, as crucial parameters. How could international law adapt to those challenges and with what cost for sovereignty? The paper was presented in the Agora "Culture As or Against Sovereignty" convened by the Interest Group on International Law of Culture as a contribution to the 2019 ESIL Conference.

Keywords: Intangible cultural heritage. UNESCO. Safeguarding. Sovereignty. International law of culture. Transboundary cultural heritage manifestations. Cultural human rights.

\section{Resumo}

O artigo explora a relação entre a soberania do Estado e a salvaguarda do Patrimônio Cultural Imaterial (doravante PCI), apontando a tensão entre uma abordagem centrada no Estado e uma abordagem orientada para a comunidade dentro do mecanismo de proteção existente. Na primeira parte, o autor delineia o arcabouço jurídico estabelecido pela Convenção da 
UNESCO de 2003, examinando algumas de suas "garantias de soberania". Na segunda parte, ela aborda a questão particular de lidar com o "PCI compartilhado" dentro da estrutura da UNESCO, examinando possíveis respostas para as deficiências aparentes para uma proteção mais eficaz. Questionando se o PCI é um campo apropriado para os Estados "reafirmarem" sua soberania ou se desafia intrinsecamente o conceito tradicional de Estado soberano, ela discute o reconhecimento do caráter transfronteiriço do PCI e a preocupação comum por sua salvaguarda, bem como a progressiva o estabelecimento do direito ao PCI e a demanda por um papel mais ativo de suas comunidades no sistema internacional de salvaguarda, como parâmetros cruciais. Como o direito internacional poderia se adaptar a esses desafios e com que custo para a soberania?

Palavras-chave: Patrimônio cultural imaterial, UNESCO, proteção, soberania, direito internacional da cultura, manifestações do patrimônio cultural transfronteiriço, direitos humanos culturais

\section{Introduction}

The international community went through a decades-long process in order to prioritize the need for the international protection of what was perceived as the "elusive" part of peoples' cultures. It, finally, vested with the well-criticized term "intangible cultural heritage" (hereafter also ICH) what was initially described as "oral heritage" or "traditional culture and folklore"1 and could not fit in the protection regime for "cultural property" or "tangible" expressions, presupposing a link to the physical consistency of heritage ${ }^{2}$. In any case, this already existent regime -described as the modern international cultural heritage law- was shaped as a distinguishable field of law during the second half of the 20th century following the establishment of $\mathrm{UNESCO}^{3}$

\footnotetext{
The first international instrument that introduced a direct reference and set the base for a holistic approach to the safeguarding of this part of cultural heritage was the 1989 UNESCO's Recommendation at a time when the term "traditional culture and folklore" was in principle used in the field; UNESCO Recommendation on the Safeguarding of Traditional Culture and Folklore, 15.11.1989 (Paris)

2 VECCO, M. A definition of cultural heritage: from the tangible to the intangible. Journal of Cultural Heritage, v. 11, 2010. p. 323-324.

3 The United Nations Educational Scientific and Cultural Organization, founded in 1945, has its headquarters in Paris, France, and consists of 193 members and 11 associate members; See: 'Member
}

and should be still viewed as a rather recent one ${ }^{4}$. During at least the last two decades, we experience a remarkably intense law-making activity in relation to the international protection of all types of cultural heritage ${ }^{5}$, either by reviewing and "updating" older instruments or by the adoption of new multilateral conventions and soft-law instruments ${ }^{7}$.

The preservation of cultural diversity -particularly threatened due to globalization's onset in contemporary world- remains the main ratio of protection. Commoditization of cultural heritage and its "management" as a "cultural asset", as often promoted by responsible actors, come to the fore at a time when the attempt to associate ICH to -also sustainable- development gains ground. Furthermore, any underlying -political, social, economic- tension is vividly expressed particularly in relation to the safeguarding of $\mathrm{ICH}$, which is by its character indissolubly connected to peoples, societies and communities, while UNESCO forums receive that tension par excellence. If culture has always been controversial as a regulatory object, ICH is, in addition, an undoubtedly conducive field for the manifestation of the fragile balances among international community's actors, something also reflected at the existing relevant regulation. Besides, it remains a new and evolving, thus dynamic field, with all the instability, as well as creativity

States', UNESCO official website, https://en.unesco.org/countries/ member-states (last accessed 14.5.2019) (hereafter UNESCO)

4 LIXINSKI, L. Between orthodoxy and heterodoxy: the troubled relationships between heritage studies and heritage law. International Journal of Heritage Studies, v. 21, n. 3, 2015. p. 204; For a brief histori$\mathrm{cal}$ analysis of this shaping see: BLAKE, J. International Cultural Heritage Law. Oxford: Oxford University Press, 2015. p. 4

FRANCIONI, F.; GORDLEY, J. (eds.). Enforcing international cultural heritage law. Oxford: Oxford University Press, 2013. p. 1.

6 As is the case, e.g., with the: Second Protocol to the Hague Convention of 1954 for the Protection of Cultural Property in the Event of Armed Conflict, 26.3.1999 (The Hague)

See indicatively: UNESCO Universal Declaration on Cultural Diversity, 2.11.2001 (Paris), UNESCO Convention on the Protection of the Underwater Cultural Heritage, 2.11.2001 (Paris), UNESCO Convention for the Safeguarding of the Intangible Cultural Heritage, 17.10.2003 (Paris), UNESCO Declaration concerning the Intentional Destruction of Cultural Heritage, 17.10.2003 (Paris), UNESCO Convention on the Protection and Promotion of the Diversity of Cultural Expressions, 20.10 .2005 (Paris). UNITED NATIONS. Declaration on the Rights of IndigenousPeoples. Availableat:https://www.ohchr.org/en/issues/ipeoples/pages/declaration.aspx Accessed on: 20 Aug. 2020.

8 M. Alivizatou, I. Poulios, M. Papadaki, 'Management of Intangible Cultural Heritage, Local Society and Sustainable Development'. POULIOS, I. (ed). Cultural management, local society and sustainable development(in greek). Athens: Hellenic Academic Libraries Link, 2015. p. 58. 
when it comes to legal proposals, that this evokes.

In this context, the debate on the nature itself and the proper ways of legal protection of the so-called "intangible cultural heritage" intensifies ${ }^{9}$, constituting in parallel a challenge for international law in an attempt to compromise States' and communities' interests over it in the context of a rather politicized debate. As a general remark, international cultural heritage law is still heavily influenced by sovereignty-based arrangements ${ }^{10}$, but some new parameters -what could be briefly described as "the human dimension of heritage law" might reasonably challenge the traditional perception of the sovereign State. However, has ICH the capacity to do so or could it serve as an ideal "silent weapon" in the hands of States in order to reaffirm their sovereignty through the established safeguarding mechanism?

Before proceeding with examining any relevant question, one should first address the notion of $\mathrm{ICH}$, since, a series of terminological questions arise with reference to all of the three components of the term. First of all, noting that defining culture itself has always been a difficult task for the legal world ${ }^{12}$, we should keep in mind that there is no common definition accepted as binding in international law and culture is used in a different way according to its inclusion in different legal instruments ${ }^{13}$. Truly understanding it would probably require turning also to anthropological analyses ${ }^{14}$, while

\footnotetext{
See some of the principal controversial questions regarding the legal protection of ICH -still existing- in: LANKARANI, L. L'avantprojet de convention de l'Unesco pour la sauvegarde du patrimoine culturel immatériel: évolution et interrogations. Annuaire français de droit international, v. 48, 2002. p. 624-656.

10 LIXINSKI, L. et al. Identity beyond borders: international cultural heritage law and the temple of preah vihear dispute. ILSA Quarterly, v. 20, n. 1, 2011. p. 37.

11 LIXINSKI, L. et al. Identity beyond borders: international cultural heritage law and the temple of preah vihear dispute. ILSA Quarterly, v. 20, n. 1, 2011. p. 37.

12 FRASER, J. Cultural heritage in transit: intangible rights as human rights ed. By Deborah Kapcha (review). Human Riguts Quartely, v. 37, n. 2, 2015. p. 556

13 See the reference in the concept of culture while analyzing the notion of "cultural life". UN COMMITTEE ON ECONOMIC, SOCIAL AND CULTURAL RIGHTS. General comment No. 21: Right of everyone to take part in cultural life (art. 15, para. 1 (a), of the ICESCR), 43 ${ }^{\text {rd }}$ Session. 2009. Availableat:https://www.refworld. org/docid/4ed35bae2.html Accessed on: 20 Aug. 2020.

${ }^{14}$ See an indicative categorization of culture "as capital", "as creativity" and "from an anthropological perspective" as "the sum total of all material and spiritual activities and products of a given social group that distinguishes it from other social groups" in: R. Stavenhagen, "Cultural Rights: A Social Science Perspective’, in NIEC, H. (ed.). Cultural Rights and Wrongs. Paris: UNESCO, 1998. p. 1-20; Besides, what is character-
}

trying to point out those elements corresponding to the various meanings of culture as used in cultural heritage law in genera ${ }^{15}$. Furthermore, cultural heritage -whose legal definition appears equally demanding- admittedly encompasses the idea of the inheritance of cultural manifestations handed down from our ancestors in order to be cared for before passing them on to our successors augmented by the creations of the present ${ }^{16}$.

As for "intangible" ce of it as a qualifier in the term ${ }^{18}$ would go beyond the scope of the present paper, it seems necessary to mention the opinion highlighting its problematic nature, which possibly leads to an also problematic use, namely the instrumentalization of heritage. On the one hand, it incorporates a certain ideological approach in favor of nearly idealistic theories accepting the existence of an "immaterial" world and favoring viewing ICH as another consumer good of contemporary capitalism, by institutionalizing a somewhat artificial division "for the needs of heritage industries"19. On the other hand, it was the term that as a working definition reached general consensus and was found the most operationally useful ${ }^{20}$, favoring the independence of that new notion from any material type of heritage, as well as marking the initiation of a new international instrument explicitly different from the 1972 World Heritage Convention $^{21}$ for the protection of "tangible" forms of cultu-

ized as "a commonly used definition" is the first scientific and classic anthropological one given by E.B. Tylor in 1871 as follows: (culture is)"that complex whole which includes knowledge, beliefs, arts, morals, laws, customs, and any other capabilities and habits acquired by [a buman] as a member of society".

15 BLAKE, J. International Cultural Heritage Law. Oxford: Oxford University Press, 2015. p. 7

16 PROTT, L. V.; O'KEEFE, P. J. Cultural heritage or cultural property? International Journal of Cultural Property, v. 1, 1992.

${ }_{17}$ The term "oral and intangible heritage" was firstly institutionally employed in the 1998 UNESCO Masterpieces Programme; UNESCO Brochure, Masterpieces of the Oral and Intangible Heritage of Humanity (Proclamations 2001, 2003 and 2005), 2006

18 See a thorough analysis on questions of terminology and definition in: BLAKE, J. Introduction to the draft preliminary study into the advisability of developing a new standard-setting instrument for the safeguarding of intangible cultural heritage. 2001. Availableat:https://ich.unesco.org/ doc/src/05358-EN.pdf Accessed on: 20 Aug. 2020. p. 7-12.

19 K. Kuutma, 'Concepts and Contingencies in Heritage Politics' ARIZPE, L.; AMESCUA, C. (ed.). Anthropological perspectives on intangible cultural heritage. London: Springer, 2013. p. 4

20 UNESCO, Executive Board, Report on the preliminary study on the advisability of regulating internationally, through a new standard-setting instrument, the protection of Traditional Culture and Folklore, $161^{\text {st }}$ session, Paris, 28.5-13.6.2001, p. 6

21 UNESCO Convention concerning the Protection of the World Cultural 
ral and natural heritage ${ }^{22}$.

Therefore, we need to clarify that for the purposes of the following analysis - despite any objections and adopting a clear position that it is a relatively newly discovered term ${ }^{23}$ and should be treated as such- ICH will be used to describe the subject matter of the International Convention for the Safeguarding of the Intangible Cultural Heritage (hereafter: 2003 UNESCO Convention $)^{24}$, which is now considered to be the central point of reference in the field. The latter will serve as the axis for the examination of the protection of this form of cultural heritage under international law, limiting our scope mainly to UNESCO framework, despite the fact that several intergovernmental organisations have also addressed questions relevant to safeguarding aspects of what we call $\mathrm{ICH}$, though mainly viewed as "traditional knowledge" or "traditional cultural expressions" 25 .

This paper will, in the first part, outline the existent safeguarding mechanism for ICH as established by the 2003 UNESCO Convention and point out some of -what we would call- the "sovereignty guarantees" in it. In the second part, the particular issue of dealing with transboundary elements of ICH and possible international law responses towards their more effective safeguarding in and beyond the UNESCO system will be examined. Besides, intangible heritage's inherent capacity and liberty to "spring up" near or on -any kind of- borders is the one that should define to a certain extent any alternative legal solution proposed regarding its protection. And this is exactly what makes the role

and Natural Heritage, 16.11 .1972 (Paris)

22 VAN ZANTEN, W. Constructing new terminology for intangible cultural heritage. Museum International, v. 56, n. 1-2, 2004. p. 39. ${ }_{23}$ KURIN, R. Safeguarding intangible cultural heritage: key factors in implementing the 2003 convention. International Journal of Intangible Heritage, v. 2, p. 9-20, 2007. p. 12

24 UNESCO Convention for the Safeguarding of the Intangible Cultural Heritage, Paris, (signed on 17.10.2003, entered into force on 20.4.2006), with 178 States Parties (as of 11.5.2018); Text of the Convention for the Safeguarding of the Intangible Cultural Heritage, UNESCO-ICH, https://ich.unesco.org/en/convention (last accessed 14.5.2019)

25 See, e.g. the work done by World Intellectual Property Organisation's (WIPO) Intergovernmental Committee on Intellectual Property and Genetic Resources, Traditional Knowledge and Folklore currently undertaking text-based negotiations with the objective of reaching agreement on a text(s) of an international legal instrument(s) for the effective protection of "traditional cultural expressions". WIPO. The protection of traditional cultural draftarticles.2018.Availableat:https://www.wipo.int/meetings/en/doc_details.jsp?doc_id=expressions: 409623 Accessed on: 20 Aug. 2020. of international law in the field even more challenging.

\section{Reaffirming Sovereignty through the UNESCO safeguarding mechanism for Intangible Cultural Heritage}

\subsection{The 2003 UNESCO Convention}

Following a long and intense process, the General Conference of UNESCO adopted during its $32^{\text {nd }}$ session the aforementioned Convention for the safeguarding of ICH. Although characterized as a successful and quickly ratified instrument, it has also given rise to strong criticism, while still traversing the very first years of the second decade of its entry into force. The Convention defines as ICH

The practices, representations, expressions,
knowledge, skills - as well as the instruments,
objects, artefacts and cultural spaces associated
therewith - that communities, groups and, in some
cases, individuals recognize as part of their cultural
heritage $^{26}$.

Characterized by its intergenerational transmission, constant recreation, interrelationship with the communities' environment, nature and history, ICH has been aptly described as "the living culture of peoples" 27 , providing them "with a sense of identity and continuity, thus promoting respect for cultural diversity and human creativity" 28 .

The core notion around which the 2003 Convention is built is that of "safeguarding", which means "measures aimed at ensuring the viability" of $\mathrm{ICH}^{29}$. This is directly related to the central legal obligations of the States Parties, since safeguarding is one of the purposes of the Convention, along with ensuring respect and mutual appreciation, raising awareness for ICH and providing for

\footnotetext{
26 UNESCO Convention 2003, art. 2\$1

7 LENZERINI, F. Intangible cultural heritage: the living culture of peoples. The European Journal of International Law, v. 22, n. 1, 2011. p. 101-120.

28 UNESCO Convention 2003, art. 2\$1

29 UNESCO Convention 2003, art. 2\$3: "including the identification, documentation, research, preservation, protection, promotion, enhancement, transmission, particularly through formal and non-formal education, as well as the revitalization of the various aspects of such heritage"
} 
international cooperation and assistance ${ }^{30}$. However, in order to research the scope of any conventional obligation, at least two remarks are necessary to be made. Firstly, safeguarding ${ }^{31}$ encompasses a wider approach to the sensitive issue of the legal protection of "a living body" ${ }^{\prime 2}$, aiming at preserving the circumstances and processes under which it is being created, preserved and transmitted rather than -according to the classical approach- protecting it against any threat ${ }^{33}$ or "physically" and "in situ" 34 . Secondly, the Convention functions parallelly at two levels, a national and an international one.

At a national level, safeguarding rests with any State Party which takes on the obligation to "take the necessary measures to ensure the safeguarding of the ICH present in its territory ${ }^{\prime 35}$. A special emphasis is given on the identification and definition of various elements of this $\mathrm{ICH}^{36}$, mainly achieved by drawing up -regularly updated and adjusted in each State's particular circumstances- inventories ${ }^{37}$. In addition, States Parties "shall endeavor" to adopt other measures, such as, among others: a general policy promoting the function of ICH in society, establishment of competent bodies for its safeguarding, appropriate legal, technical, administrative and financial measures, assurance of recognition and respect for ICH through educational, awareness-raising and information programmes ${ }^{38}$.

At an international level, States Parties concerned may submit their proposals to the Intergovernmental Committee for the Safeguarding of ICH (hereafter also IGC ${ }^{39}$ which establishes, keeps up to date and publishes the "Representative List of the ICH of Humanity"

30 UNESCO Convention 2003, art. 1

31 For the explicit choice of the term "safeguarding" unlike "protection" in the 2003 UNESCO Convention, see: UNESCO, Meeting of the "Restricted Drafting Group", Preparation of a preliminary draft International Convention on the ICH, Paris, 20-22.3.2002, para. 17

32 UNESCO Brochure, Questions and Answers about Intangible Cultural Heritage, p. 3

33 BLAKE, J. International Cultural Heritage Law. Oxford: Oxford University Press, 2015. p. 12

34 FORREST, C. International Law and the Protection of Cultural Heritage. United Kingdom: Routledge, 2010. p. 14-18.

35 UNESCO Convention 2003, art. 11(a)

36 UNESCO Convention 2003, art. 11(b)

37 UNESCO Convention 2003, art. 12

38 UNESCO Convention 2003, art. 13, 14

39 UNESCO Convention 2003, art. 5-9; For more information see: Functions of the Intergovernmental Committee for the Safeguarding of ICH (henceforth IGC), UNESCO-ICH, https://ich.unesco. org/en/functions-00586 (last accessed 16.5.2019)

40 UNESCO Convention 2003, art. 16
(429 elements inscribed corresponding to 117 countries as of December 2018), the "List of ICH in Need of Urgent Safeguarding" 41 (59 elements inscribed corresponding to 32 countries), as well as the "Register of Good Safeguarding Practices" ${ }^{\prime 2}$ (20 elements inscribed corresponding to 16 countries) by selecting and promoting safeguarding programmes, projects and activities which it considers best reflect the principles and objectives of the Convention ${ }^{43}$. Furthermore, States submit periodic reports on the legislative, regulatory and other measures taken for the implementation of the Convention to the Committee, which in its turn submits them to the General Assembly of the States Parties ${ }^{44}$ at each of its sessions, bringing them to the attention of the General Conference of UNESCO too ${ }^{45}$, a process that somehow counterbalances the absolute absence of a compliance mechanism ${ }^{46}$.

In the whole safeguarding system, prominence is given to the "communities, groups and individuals" - bearers of ICH. They are acknowledged as those playing "an important role in the production, safeguarding, maintenance and recreation" of $\mathrm{it}^{47}$, but most importantly they are the ones who by definition recognize the manifestations of ICH "as part of their cultural heritage" ${ }^{\prime 4}$. In the first place, this prerequisite adds two significant parameters in relation to the cultural heritage protection regime existent prior to the 2003 Convention. On the one hand, the self-recognition by communities themselves of ICH as part of their heritage ${ }^{49}$, contrary to the perception of the "outstanding universal value" of the world cultural and natural (tangible)

\footnotetext{
$41 \quad$ UNESCO Convention 2003, art. 17

42 UNESCO Convention 2003, art. 18

43 See all the elements inscribed on those three international lists at: 'Browse the Lists of ICH and the Register of good safeguarding practices', UNESCO-ICH, https://ich.unesco.org/en/lists (last accessed 16.5.2019)

44 UNESCO Convention 2003, art. 4; For more information see: Functions of the General Assembly of the States Parties to the 2003 Convention, UNESCO-ICH, https://ich.unesco.org/en/ functions-00710 (last accessed 16.5.2019)

45 UNESCO Convention 2003, art. 29, 30

46 KURUK, P. Cultural heritage, traditional knowledge and indigenous rights: an analysis of the convention for the safeguarding of intangible cultural heritage. Macquarie Journal of International and Comparative Environmental Law, v. 1, 2004. p. 133.

47 UNESCO Convention 2003, preamble, para. 7

48 UNESCO Convention 2003, art. 2\$1

49 LENZERINI, F. Intangible cultural heritage: the living culture of peoples. The European Journal of International Law, v. 22, n. 1, 2011.
} p. 108. 
heritage ${ }^{50}$. On the other hand, the representativeness of ICH elements ${ }^{51}$, unlike the former characterization of the "masterpieces" of heritage ${ }^{52}$. In the second place, it introduces us into the crucial issue of the central role the Convention accords to the cultural communities associated with $\mathrm{ICH}^{53}$ and the question of their participation in the safeguarding mechanism, reflected also at the States Parties' obligations ${ }^{54}$. However, it is important to examine the extent of this participation at a national level, which is not always reassured given the absence of legal guarantees. At the same time, the demand for their more active involvement at the international level ${ }^{55}$, in practice "ensured" through the requirement for their "prior, free and informed consent" for an inscription on the Lists ${ }^{56}$, remains and constitutes one of the mostly discussed topics ${ }^{57}$.

\subsection{Sovereignty "guarantees" in the UNESCO safeguarding mechanism}

Having mentioned the central points of the conventional mechanism, the following analysis shall focus on some of its interrelated elements which serve as "pillars" that States may "use" with a view to ensuring respect for or in some way reaffirming their sovereignty ${ }^{58}$.

As a first pillar, the sovereign body of the 2003 Con-

50 UNESCO World Heritage Convention 1972, art. 1

51 LIXINSKI, L., Intangible Cultural Heritage in International Law. Oxford: Oxford University Press, 2013. p. 36.

52 UNESCO Masterpieces 2001, 2003, 2005

53 BLAKE, J. Commentary on the 2003 UNESCO Convention on the Safeguarding of the Intangible Cultural Heritage. New York: Institute of Art and Law, 2006; SMITH, L.; AKAGAWA, N. (ed.). Intangible heritage. Abingdon, United Kingdom: Routledge, 2009. p. 45

54 UNESCO Convention 2003, art. 11 (b), 15

55 LIXINSKI, L., Intangible Cultural Heritage in International Law. Oxford: Oxford University Press, 2013. p. 53

56 UNESCO, Operational Directives for the Implementation of the Convention for the Safeguarding of the Intangible Cultural Heritage, adopted by the General Assembly of the States Parties to the Convention at its 2nd session (UNESCO Headquarters, Paris, 16-19.6.2008), as amended into their last version (2018), para. 1 (U.4.), 2 (R.4.), 7 (P.5.)

57 See as an indicative example: UNESCO, IGC, Report of the Rapporteur of the subsidiary body on the modalities for the participation of communities or their representatives, practitioners, experts, centres of expertise and research institutes in the implementation of the Convention, $2^{\text {nd }}$ Extraordinary Session, Sofia, Bulgaria, 18-22.2.2008

58 Besides, the "sovereignty issue" was always apparent in the drafting period. E.g.: "A call was made to specify minimum standards for Parties (as does TRIPS) and to take caution in ceding State sovereignty." in: UNESCO, First meeting of the select drafting group of a preliminary international convention on ICH, Final Report, Paris, 20-22.3.2002, Discussion Unit 6 - Article 2 on State Sovereignty, p. 6 vention is the General Assembly of the States Parties. This was a definite choice among States participating in the drafting of the Convention when it was felt that sovereignty should be strengthened also by creating such a body as the supreme authority on most matters regarding its implementation ${ }^{59}$. However, the need for a more specialized body, competent to deal with particular issues was also apparent ${ }^{60}$. But even the IGC -which was chosen to be that body- is composed of State representatives, thus deemed as one more "safety valve" for sovereignty ${ }^{61}$. Besides, the Convention has been criticized for consciously neglecting non-State actors regarding some of its critical aspects, one of which is certainly the composition of the decision-making bodies.

Nonetheless, the lack of independent experts is attempted to be covered ex post facto. The IGC has the capacity to "invite to its meetings any public or private bodies" and "persons [...] including communities, groups, and other experts" ${ }^{2}$, to "propose the accreditation of NGOs to act in an advisory capacity" and to "establish ad hoc consultative bodies"63. Thus, it has established most recently (starting with 2015 cycle) a

59 LIXINSKI, L. Selecting heritage: the interplay of art, politics and identity. European Journal of International Law, v. 22, 2011. p. 86; It is characteristic that those concerns were clearly raised during the drafting period. See, e.g., the position of Barbados, Saint Lucia and Czech Republic expressed in their amendments to the preliminary draft convention in: UNESCO, Second session of the Intergovernmental Meeting of Experts on the Preliminary Draft Convention for the Safeguarding of the ICH, Compilation of amendments from Member States concerning the Convention for the Safeguarding of the ICH, Paris, 24.2-1.3.2003, footnotes 919, 922, 948; Following those amendments, a new article (as art. Z) in which the General Assembly is established as the Convention's sovereign body was for the first time included in the consolidated preliminary draft convention as proposed by the Intersessional Working Group of government experts to the Third session of the Intergovernmental Meeting of Experts on the Preliminary Draft Convention for the Safeguarding of the ICH $(06 / 2003)$. See that in: UNESCO, Intersessional Working Group of government experts on the Preliminary Draft Convention for the Safeguarding of the ICH, Report by Pr. C. Economides, Paris, 22-30.4.2003, para. 18

60 BLAKE, J. Commentary on the 2003 UNESCO Convention on the Safeguarding of the Intangible Cultural Heritage. New York: Institute of Art and Law, 2006. p. 45.

${ }_{61}$ This remark could be examined in relation to previous UNESCO Conventions where it was either chosen not to establish the General Assembly of the States Parties as the sovereign body of the Convention (1972 World Heritage Convention) or to give prominence to the establishment of a scientific body of experts directly by the Meeting of States Parties (2001 Convention on the Protection of the Underwater Cultural Heritage).

62 UNESCO, Operational Directives 2016, para. 89

63 UNESCO Convention 2003, art. 8\$4, art. 9, art. $8 \$ 3$ 
single Evaluation Body as a consultative one ${ }^{64}$, replacing the preceding Consultative and Subsidiary Bodies. Composed by six qualified experts representatives of States Parties non-Members of the Committee and six accredited NGOs, it is responsible for primarily evaluating States' nominations to the Lists and making recommendations to the IGC for its final decisions ${ }^{65}$. Beyond the primary observation that even the Evaluation Body's members cannot be characterized by guarantees of absolute independence -as appointed by their State at the end of the day-, the criticism on the credibility of the evaluation process for the exclusion or inclusion of elements in the Lists ${ }^{66}$ and on the whole procedure until the final decisions ${ }^{67}$-within a framework of inevitably politically tense Committee sessions- seems reasonable too.

As a second pillar, the parameter of place and territory in relation to ICH's safeguarding is of crucial importance for the function of the conventional mechanism. And this is beyond any recognition of the dialectical relationship between ICH and space or persons and their environment. The latter is apparent when examining either all those "place-based" ICH elements and cultural spaces ${ }^{68}$ associated with ICH manifestations and included in its definition, or by admitting that communities recreate their ICH "in response to their environment and their interaction with nature" ${ }^{\prime 9}$. However, this reference to place -at least in principle- should not be interpreted as establishing any fixed link between

${ }_{64}$ In conformity also with the Operational Directives: UNESCO,
Operational Directives 2018, para. 27
65 UNESCO, IGC, Decisions, 9th session, Paris, 24-28.11.2014, DECISION 9.COM 11, para. 7; 'Evaluation Body', UNESCO-ICH, https://ich.unesco.org/en/evaluation-body-00802 (last accessed 30.05.2019)

${ }^{66}$ R. Rosaldo, 'Evaluation of Items on Intangible Cultural Heritage’ ARIZPE, L.; AMESCUA, C. (ed.). Anthropological perspectives on intangible cultural heritage. London: Springer, 2013. p. 37-38

${ }^{67} \mathrm{R}$. Smeets and H. Deacon 'The examination of nomination files under the UNESCO Convention for the Safeguarding of the Intangible Cultural Heritage'. STEFANO, M. L.; DAVIS, P. (ed.). The Routledge Companion to intangible cultural heritage. Abingdon, United Kingdom: Routledge, 2017. p. 32-33.

68 Interestingly, as generally accepted, the urgent need to safeguard Jemaa el-Fna square in Marrakesh from the onset of the surrounding economic development as "oral heritage of humanity" was the decisive spark for the adoption of the newly discovered notion of "safeguarding ICH" by UNESCO; SCHMITT, T. M. The UNESCO concept of safeguarding intangible cultural heritage: its background and marrakchi roots. International Journal of Heritage Studies, v. 14, n. 2, 2008. p. 95-111.

69 UNESCO Convention 2003, art. $2 \$ 1$
ICH and a geographical space, but merely as highlighting the role of the social, political or natural context in the recreation of the cultural practice ${ }^{70}$.

In this context, place becomes a pivotal axis for safeguarding ICH through the establishment of States' legal obligation to ensure the safeguarding of ICH "present in their territory" "1. This prerequisite has two important implications directly relevant to ensuring respect for State sovereignty. Firstly, it implies that ICH is also defined on the basis of present State territories, despite the fact that no such strict geographical condition is enshrined in its conventional definition. Secondly, a territorial clause is enshrined in the Convention, characterizing the most crucial aspect of the safeguarding mechanism, as well as a territorial condition for the inscription of elements on any List is established by extension. Thus, the answer to the central question "who acts and for which intangible heritage" is that legally responsible for ICH safeguarding is of course the State, but its obligation extends only to that $\mathrm{ICH}$ within its territory. The latter might seem necessary for the proper function of the system in accordance with the traditional perception of the role of the State in international law. Though, we cannot disregard the inherent contradiction in presenting ICH closely linked to its bearers as much as to a given territory, something that may result in limiting the object of protection in a way incompatible with its nature. Besides, a serious concern is raised on the aforementioned issues even since the drafting period and it seems that the Convention takes a clear position on them ${ }^{72}$.

As a third pillar, UNESCO safeguarding mechanism is founded on a specific model, the international expression of which is the creation and constant update

\footnotetext{
${ }^{0}$ C. Bortolotto, 'Placing intangible cultural heritage, owning a tradition, affirming sovereignty: the role of spatiality in the practice of the 2003 Convention'. STEFANO, M. L.; DAVIS, P. (ed.). The Routledge Companion to intangible cultural heritage. Abingdon, United Kingdom: Routledge, 2017. p. 48.

71 UNESCO Convention 2003, art. 11, 12, 13, 23

72 See, e.g. the conversation in the context of the select drafting group on those matters: "It was suggested that the idea of "present" is important as providing the necessary temporal element that characterises IH as evolving and migratory. A further suggestion was a formulation such as "with links with the population situated on the territory". [An alternative proposal not supported was "practised by its citizens"]. [...] Although the issue of transboundary IH was raised, it was felt that any reference to extra-territoriality of State jurisdiction should be avoided." in: UNESCO, First meeting of the select drafting group of a preliminary international convention on $\mathrm{ICH}$, Final Report, Paris, 20-22.3.2002, Discussion of Unit 8 - Article 4, p. 7
} 
of Lists of elements "to be protected", following State proposals. At a first level, apart from any criticism on the choice of inventory making as an appropriate way of heritage protection in general ${ }^{73}$, its application especially in the field of ICH expressively points out its own deficiencies ${ }^{74}$. On the one hand, Lists could ensure better visibility, increase awareness, encourage dialogue that respects cultural diversity ${ }^{75}$ and contribute to identifying ICH. On the other hand, their choice as the predominant protection means at the international level ${ }^{76}$ guarantees neither the effective safeguarding of a so-called "living heritage" ${ }^{77}$ nor the unbiased process of nominations and decision making on elements' inscriptions by the $\mathrm{IGC}^{78}$.

At a second level, the listing system in total eventually functions as another favourable stage for reaffirming sovereignty as a result of the purely State nominations in combination with the application of the territorial condition for the inscription of ICH elements on the Lists $^{79}$, as already mentioned. This mechanism favors

\footnotetext{
73 SCHUSTER, J. M. Making a list and checking it twice: the list as a tool of historic preservation. 2002. Availableat: https://ideas.repec. org/p/har/wpaper/0303.html Accessed on: 20 Aug. 2020.

74 It was one of the most controversial issues during the preconventional negotiations. See, e.g.: UNESCO, $2^{\text {nd }}$ Session of the Intergovernmental Meeting of Experts on the Preliminary Draft Convention for the Safeguarding of ICH, Position des Etats Membres en egard au principe de liste(s) du patrimoine culturel immaterial-7 Octobre 2002, Paris, 24.2-1.3.2003
}

75 UNESCO, Expert Meeting on the Lists Established in the 2003 Convention for the Safeguarding of the Intangible Cultural Heritage, Summary report of the meeting, New Delhi, India, 2-4.4.2007, p. 5, para. II

${ }_{76}$ In fact, their establishment was inspired once again by the 1972 UNESCO World Heritage Convention which initiated the "World Heritage List" (art. 11) and came as a natural continuity of the 1998 Proclamation of "Masterpieces" since the elements inscribed on it were directly incorporated in the Representative List of the ICH of Humanity according to the 2003 Convention (art. 31); See more in: N. Aikawa-Faure, 'From the Proclamation of Masterpieces to the Convention for the Safeguarding of Intangible Cultural Heritage' in: SMITH, L.; AKAGAWA, N. (ed.). Intangible heritage. Abingdon, United Kingdom: Routledge, 2009. p. 13-14.

${ }_{77}$ A reasonable objection highlights the tendency to "freeze" ICH elements in time and not encourage cultural vitality through listing; See some aspects of the issue in: KURIN, R. Safeguarding intangible cultural heritage in the 2003 UNESCO Convention: a critical appraisal. Museum International, v. 56, n. 1-2, 2004. p. 71-72.

78 Some of the questions raised are among others the nature of the selection criteria and process, the type of the documenting material accompanying the proposals, the existent difficulties in documenting and archiving ICH. See the experts' debate on some interesting topics in: UNESCO, Expert meeting on documentation and archiving of ICH, Meeting Report, Paris, France, 12-13.1.2006

${ }^{79}$ In practical terms, a section titled "geographical location and not only the manifestation of tensions between States -and also between communities- using it for ultimate purposes other than the ones enshrined in the Convention but may also lead to the exclusion in essence of communities, groups and individuals concerned from the international dimension of its application ${ }^{80}$. In fact, a form of hierarchy, elitism and fragmentation among ICH elements (included or not in the Lists) around the world is inevitably created, since "lists itemize culture" as aptly written ${ }^{81}$. Consequently, representativeness and equality among them is questioned, while a tendency to be promoted as "national products" in the international market exists ${ }^{82}$.

In particular, various elements already inscribed on the Lists are either directly presented as "national" or their "national" character is implied/stated even in their definition and name ${ }^{83}$. Besides, there are cases of States participating in inventorying ICH elements at the international level while in parallel declaring State copyright over them through their domestic laws ${ }^{84}$ or a direct connection of ICH to the "nation" 85 . In other cases,

range of the element" is enshrined in the nomination forms: 'Forms to be used for nominations, proposals, assistance requests, accreditation requests and periodic reporting', UNESCO-ICH, https://ich. unesco.org/en/forms (last accessed 30.06.2019)

80 The only way to prove community participation in the international nomination process is through the evidence provided by States for their consent (established as letters of consent until today) accompanying the nomination file, something that could be strongly questionable as a process.

${ }_{81}$ V.T. Hafstein, 'Intangible heritage as a list: from masterpieces to representation'. SMITH, L.; AKAGAWA, N. (ed.). Intangible heritage. Abingdon, United Kingdom: Routledge, 2009. p. 105

82 BLAKE, J. International Cultural Heritage Law. Oxford: Oxford University Press, 2015. p. 244

83 E.g. "Albanian folk iso-polyphony" (Inscribed in 2008 (3.COM) on the RL of the ICH of Humanity (originally proclaimed in 2005), "Palestinian Hikaye" (Inscribed in 2008 (3.COM) on the RL of the ICH of Humanity (originally proclaimed in 2005), "Georgian polyphonic singing" (Inscribed in 2008 (3.COM) on the RL of the ICH of Humanity (originally proclaimed in 2001), "Fado, urban popular song of Portugal" (Inscribed in 2011 (6.COM) on the RL of the ICH of Humanity), Armenia's nomination's title of "Lavash, the preparation, meaning and appearance of traditional Armenian bread as an expression of culture" was changed as "in Armenia" after reactions by Azerbaijan and Iran and finally inscribed on the RL in 2014, while also as "Flatbread making and sharing culture Lavash, Katyrma, Jupka, Yufka” by Azerbaijan, Iran, Kazakhstan, Kyrgyzstan, Turkey in 2016.

${ }_{84}$ E.g., Indonesia has inscribed 9 elements (2008-2017) on ICH Lists while stating in its copyright law: Law of the Republic of Indonesia on Copyright - No. 19/2002, 29.7.2002, art. 10\$2: "The State shall hold the Copyright for folklores and works of popular culture that are commonly owned [...]".

85 China has inscribed 40 elements (2008-2018) on ICH Lists while 
they use Lists "as a race or contest, seeking to have elements inscribed before other States manage to do so" ", in order to somehow "get a patent or copyright" on elements presented as exclusively "national", present only in a certain State's territory, unique and having a sole "country of origin" " Within this framework, what is frequently noticed is an attempt to promote a common national identity and integrate minority cultural expressions in the "official culture" of the State ${ }^{88}$, as well as some "conflicting" inscriptions of the same elements by different States ${ }^{89}$. At the same time, States are likely

stating in its law on ICH: "This Law is formulated for the purposes of inheriting and promoting the distinguished traditional culture of the Chinese nation [...]". BEN SHE. Law of the people's republic of china on intangible cultural heritage. New York: Law Press, 2011.

86 UNESCO, $6^{\text {th }}$ Session of the IGC, Item 8 of the Provisional Agenda: Evaluation of nominations for inscription in 2011 on the List of ICH in Need of Urgent Safeguarding, Bali, Indonesia, 22-29.11.2011, para. 26

87 E.g., see such an analysis on the basis of the inscription of "Karagöz" by Turkey on the RL in 2009 and its "conflict" with Greece for the shadow theatre of "Karagiozis" in: AYKAN, B. Patenting Karagöz: UNESCO, nationalism and multinational intangible heritage. International Journal of Heritage Studies, v. 21, n. 10, 2015. p. 949; Turkey has also inscribed the "Turkish coffee culture and tradition" on the RL in 2013, while the same element is widely called "the Greek coffee" in Greece and could possibly lead to a similar "conflict". In fact, the Committee in 2013 recognized the existence of the same tradition outside the country though still characterizing it "Turkish": UNESCO, 9th Session of the IGC, Item 4 of the Provisional Agenda: Adoption of the summary records of the eighth session of the Committee, 24-28.11.2014, para. 725: "Turkish coffee culture and tradition was a very strong element of ICH in Turkey, but also in a broader geographic region that included the Balkans, the Caucuses, the Mediterranean and the Middle East."

88 E.g., according to criticism expressed by scholars, this was the case with the inscription of the "Tibetan Opera" as a cultural expression of "minority ethnic groups" by China on the RL in 2009; This was also the case with "Nawrouz" celebration regarding Turkey and dealing with Kurdish communities, when Turkey presented it as a "Turkish spring holiday" in order to dissociate it from the Kurdish identity in the context of its multinational inscription on the RL in 2016, along with Afghanistan, Azerbaijan, India, Iran (Islamic Republic of), Iraq, Kazakhstan, Kyrgyzstan, Uzbekistan, Pakistan, Tajikistan, Turkmenistan. It is notable that community concern regarding Turkey in the nomination was exclusively provided by Turkish Associations.

89 E.g., the inscription of the same type of 'Mongolian traditional art of Khöömei throat singing' on the RL by China in 2009 and Mongolia in 2010, of the same traditional horse-riding game as "Chovqan a traditional Karabakh horse-riding game in the Republic of Azerbaijan" by Azerbaijan in 2013 on the List of ICH in Need of Urgent Safeguarding and as "Chogān a horse-riding game accompanied by music and storytelling" by Iran in 2017 on the RL, as well as of the same festival as "Gangneung Danoje festival" by the Republic of Korea in 2008 (originally proclaimed in 2005) and as "Dragon Boat festival" by China in 2009 on the RL. This issue is already recognized as of great importance by the Consultative Body and the IGC as manifested in the case of the decision of the first not to present for evaluation two nominations to the IGC on to "reconstruct" and adjust ICH manifestations in order to fit them better in the listing patterns which might even change the relationship of social actors to their culture or try to "hide" some of the element's real characteristics ${ }^{90}$.

Finally, it is apparent from the above that this mechanism does not protect ICH "from being harmed by the action or in-action of the State in which it originates" $"$, thus no claim against the State itself could be ever founded with the existent tools. Besides, this was an existent concern in the drafting period and it seems that the respect for sovereignty was once again put in the forefront ${ }^{92}$. Furthermore, the aforementioned mechanism may also lead to the exclusion in essence of communities, groups and individuals concerned from the international dimension of its application, in the absence of sufficient legal guarantees for that. In parallel, it automatically creates a grey zone with regard to all those transboundary ICH elements that cannot "fit in" the territorial condition. As a result, the discussion leads us to the controversial issue of how the existent system deals or should deal with "shared" ICH.

the grounds that "they were identical to one another" during the 2011 round, while noting that "the communities concerned were overlapping" in: UNESCO, $6^{\text {th }}$ Session of the IGC, Item 7 of the Provisional Agenda: Report of the Consultative Body on its work in 2011, Bali, Indonesia, 2229.11.2011, para. 16

90 See, e.g., a critical analysis of the proclamation of the "Carnival of Binche" (celebrated in a French-speaking part of Belgium near France) as masterpiece of the Oral and Intangible Heritage of $\mathrm{Hu}$ manity by Belgium in 2003 and its inscription on the RL in 2008, which led to a distortion of the description of its characteristics regarding women participation in it, in: M. Tauschek, 'Imaginations, Constructions and Constraints: Some Concluding Remarks on Heritage, Community and Participation' in ADELL, N.; BENDIX, R. F. et al. (eds). Between Imagined Communities and Communities of Practice. Göttingen Studies in Cultural Property, v. 8, 2015. p. 298-301

91 LIXINSKI, L., Intangible Cultural Heritage in International Law. Oxford: Oxford University Press, 2013. p. 52

92 See, e.g., Switzerland's position: "The protection of ICH can only really be effective if it is the result of close international cooperation. It therefore regrets that on the basis of the principle of respect for national sovereignty, all attempts to codify [the right of] intervention on cultural grounds seem to have been abandoned. In the view of Switzerland, this measure renders meaningless the principle of protection of the cultural heritage as part of the heritage of bumanity. And yet, several grave violations of this heritage, including the recent deliberate destruction of the Buddhist statues at Bâmiân in Afghanistan, ought to prompt us to consider intervention by the international community in order to ensure the protection of such property." In UNESCO, Second session of the Intergovernmental Meeting of Experts on the Preliminary Draft Convention for the Safeguarding of the ICH, Compilation of amendments from Member States concerning the Convention for the Safeguarding of the ICH, Paris, 24.2-1.3.2003, footnote 793 


\section{3 "Shared Intangible Cultural Heritage" and possible responses in terms of international law}

\subsection{Dealing with "shared Intangible Cultural Heritage" within the UNESCO safeguarding mechanism}

ICH's character reveals its capacity to transcend national borders par excellence and in some cases flourish near or on them, which means that $\mathrm{ICH}$ cannot reasonably be defined in relation to territories despite any direct or indirect attempt on the basis of the 2003 Convention ${ }^{93}$, as is the case with culture itself $\mathrm{f}^{94}$. Besides, "political geography" that shapes modern States does not always overlap with "cultural geography" that forms communities of specific heritage elements and one could argue that the concept of territorial sovereignty does not even make sense in the context of cultural heritage preservation ${ }^{95}$. In fact, the main criticism should be founded on the inherent contradiction of the UNESCO mechanism in trying to "compromise" a community-oriented approach with a State-centered one. On the one hand, there are ICH elements which could be described as "being present" in the territories of more than one States ${ }^{96}$. On the other hand, how could we even talk about ICH "present in a territory" when this heritage is normally "present" wherever its people are ${ }^{97}$ ? This issue has some rather important dimensions in as-

\footnotetext{
93 See the criticism for "the mapping of cultures into bounded and distinct places" which was a dominant trend at the time of the adoption of the 2003 Convention when UNESCO was facing postcolonial developments in: Bortolotto, The Routledge Companion, p. 48

94 'The entire concept of culture defies using geopolitical boundaries as demarcations since culture is neither normally nor bistorically derived from a territory'. VERNON, M. C.Common cultural property: the search for rights of protective intervention. Case Western Reserve Journal of International Law, v. 26, n. 2, 1994. p. 446.

95 EAGEN, S. Preserving cultural property: our public duty: a look at how and why we must create international laws that support international action. Pace International Law Review, v. 13, n. 2, 2001. p. 443. 96 C. Amescua, 'Anthropology of Intangible Cultural Heritage and Migration: An Uncharted Field' ARIZPE, L.; AMESCUA, C. (ed.). Anthropological perspectives on intangible cultural heritage. London: Springer, 2013. p. 103-120.

${ }_{97}$ The characterization of ICH as "living heritage embodied in people" is often used among scholars and in UNESCO wording: LOGAN, W. Cultural diversity, cultural heritage and human rights: towards heritage management as human rights-based cultural practice. International Journal of Heritage Studies, v. 18, n. 3, 2012. p. 241.
}

sociation with refugee crisis and migration ${ }^{98}$, people of diaspora $^{99}$, nomadic communities and minorities present in a territory, as well as cross-border communities with common cultural characteristics ${ }^{100}$. The application of the aforementioned mechanism at their case is particularly problematic, mainly due to some progressively dominant ideas emphasizing sovereignty. Namely, the use of the ICH legal safeguarding system in favor solely of the nation-State, by presenting ICH as "present in a territory" or vested with a certain State coinciding with a culturally homogeneous nation ${ }^{101}$.

As a response to the existent deficiency, UNESCO system has moved on to include a provision for joint submission of "multi-national nominations" for inscription of elements "found on the territory of more than one State Party" on ICH Lists ${ }^{102}$. In parallel, States Parties "undertake to cooperate at the bilateral, subregional, regional and international levels" ${ }^{\prime 103}$, while encouraged to develop joint initiatives "particularly concerning elements of ICH they have in common"104. However, apart from the Convention's non-normative and always flexible wording and despite having initiated a "mechanism to encourage multinational files" by publicly declaring -on a voluntary basis- the intention for a future nomination ${ }^{105}$, the process

98 NETTLEFORD, R. Migration, transmission and maintenance of the intangible heritage. Museum International, v. 56, n. 1-2, 2004. p. $78-83$

99 BLAKE, J. International Cultural Heritage Law. Oxford: Oxford University Press, 2015. p. 282-283

100 "Examples abound everywhere in the world: Mongolians live on both sides of the Mongolian-Chinese border; Turkmen and Uzbeks are also found in Afghanistan; Yoruba are spread over Nigeria, Ghana, Togo and Benin; Maasai live in Kenya and Tanzania; Berbers live in adjacent parts of Morocco and Algeria, and elsewhere in pockets in the North of Africa, where once they occupied a large territory; Guarani live in Paraguay, Brazil and Argentina and Basques and Catalans on both sides of the French-Spanish border" in: UNESCO, Intangible Heritage Beyond Borders: Safeguarding Through International Cooperation-Regional Meeting, Background paper, Bangkok (Thailand), 20-21.7.2010

101 Besides, "culture in itself is not extraneous to the formation of the modern nation State": FRANCIONI, F. Beyond state sovereignty: the protection of cultural heritage as a shared interest of humanity. Michigan Journal of International Law, v. 25, 2004. p. 1210; See the initiation of the interesting notion of "imagined communities" ANDERSON, B. Imagined communities: reflections on the origin and spread of nationalism. London, New York: Verso, 2006.

102 UNESCO, Operational Directives 2018, paras. 13, 14; The extension of an existent inscription is also encouraged in paras. 16-19 of the Operational Directives.

103 UNESCO Convention 2003, art. 19

104 UNESCO, Operational Directives 2018, para. 86

105 'Sharing information to encourage multinational files', UNESCO-ICH, https://ich.unesco.org/en/mechanism-to-encouragemultinational-files-00560 (last accessed 30.06.2019); It has been es- 
discloses its own narrow limits. It is normal that the preparation of a multinational proposal is absolutely dependent on the consent of concerned States on the basis of their sovereign right to decide $\mathrm{it}^{106}$ and seems a particularly complex process. As a result, nothing could be done if one of them does not want to move on to it, does not have the sufficient resources to do so, has not ratified the Convention or has rival relations with the other one(s).

It is noteworthy, though, that UNESCO explicitly recognizes the problem and moves on to talk about "shared ICH", declaring that the only appropriate solution to it is State cooperation and submission of multinational files. For what is more, the recognition at least at a declaratory level of the existence of -also transboundary- communities sharing a common heritage $\mathrm{e}^{107}$ has not led to any practical proposals for their case so far. Most importantly, an attempt was made to approach the issue during a regional consultation meeting of government representatives and experts under the auspices of UNESCO in 2010, which, although having concluded on some critical statements on "diffuse heritage and diffuse communities"

tablished as an on-line resource by a decision of the IGC in 2012, stating that ICH "is often shared by communities on the territories of more than one State": UNESCO, IGC, Decisions, 7th session, UNESCO Headquarters, Paris, 3-7.12.2012, DECISION 7.COM 14, p. 68, para. 4; It is noteworthy that this procedure has not proved to be successful, since it has been followed until today only by Iran (twice in 2015) and Saudi Arabia (once in 2018).

106 This is highlighted in: UNESCO, IGC, Item 10 of the Provisional Agenda: Report of the Subsidiary Body on its work in 2014 and examination of nominations for inscription on the RL of the ICH of Humanity, $9^{\text {th }}$ session, UNESCO Headquarters, 24-28.11.2014, p. 10, para. 33

107 "The spirit of the Convention is such that communities should be seen as having an open character, not necessarily linked to specific territories" in: UNESCO Brochure, Implementing the Convention for the Safeguarding of the ICH, p. 8; "The communities and groups that are the bearers, practitioners and stewards of ICH often live on both sides of an international border, and their heritage may be expressed in similar or identical ways, despite the fact that they are residents of different countries. [...] Examples of ICH shared across international borders are plentiful. [...] When safeguarding an element is at stake, better results will be achieved with the full participation of the whole community, regardless of its geographic location." in UNESCO, IGC, Item 14 of the Provisional Agenda: Mechanism for sharing information to encourage multinational nominations, 7 th session, UNESCO Headquarters, 3-7.12.2012, p. 2, paras. 1-3

108 "When we are speaking about the location or distribution of ICH elements, we are also speaking about the location and geographical distribution of the people involved in them [...] When their territory is split up by an imposed State border, the community continues to exist, and so does its ICH, becoming heritage shared across national borders [...] A community and its ICH may be found in one contiguous area, which may be located within one State, but which may also be spread over adjacent States" in: UNESCO, Intangible non-correspondence of States Parties towards the international cooperation clause to questions of willingness and politics, again without any proposal.

Nevertheless, the IGC's concern on managing cases of "TCH shared across borders" is more and more apparent with a strong emphasis on respect for sovereignty, reaching even the point to "remind" States of the "sensitivities" and the "necessity to take care when elaborating" multinational nominations ${ }^{109}$. It has also acknowledged for the first time "the sovereign right of each State Party to nominate elements found on its territory, regardless of the fact that they may also exist elsewhere" 110 and not just "to decide" whether to submit a nomination. At the same time, States Parties' and the IGC's dominant conception of the relation between respect for sovereignty and the safeguarding of shared manifestations of ICH in the context of the conventional mechanism is still very narrow and could be briefly described in the following statements. On the one hand,

"Although nominations are to be elaborated with the widest possible participation of the community [...] concerned, each State's respect for the sovereignty of its neighbours constrains it from involving community members living outside of its own territory" 111 .

On the other,

Nominations to the RL should concentrate on the situation of the element within the territory(ies) of the submitting State(s), while acknowledging the existence of same or similar elements outside its(their) territory(ies), and submitting States should not refer to the viability of such ICH outside of their territories or characterize the safeguarding efforts of other States ${ }^{112}$.

Heritage Beyond Borders: Safeguarding Through International Cooperation-Regional Meeting, Background paper, Bangkok (Thailand), 20-21.7.2010

109 UNESCO ICH Section, Aide-mémoire for completing a nomination to the RL of the ICH of Humanity for 2016 and later nominations, p. 20, para. 45, available at: https://ich.unesco.org/en/forms (last accessed 30.06.2019); It is notable that these statements are made under the title "Shared Heritage: Sovereignty of each State" of the Aide-mémoire.

110 UNESCO ICH Section, Aide-mémoire for completing a nomination to the RL of the ICH of Humanity for 2016 and later nominations, p. 20, para. 45, available at: https://ich.unesco.org/en/forms (last accessed 30.06.2019)

111 UNESCO, IGC, Item 14 of the Provisional Agenda: Mechanism for sharing information to encourage multinational nominations, 7 th session, UNESCO Headquarters, Paris, 3-7.12.2012, p. 2, para. 2

112 UNESCO, IGC, Decisions, 6th session, Bali, Indonesia, 2229.11.2011, DECISION 6.COM 13, para. 11; See also an interesting analysis questioning the lawfulness of the IGC's decisions on this territorial condition, which however concludes in favor of it, 
Furthermore, a remarkably new prerequisite -in relation to the conventional text- has been established as "a technical requirement" for the proposals towards the Representative Lists, namely the previous inscription of the element in nominating State's national inventory ${ }^{113}$, which by definition contains ICH elements "present in its territory "114. However, the Committee surprisingly recognizes that States' legal obligation to safeguard ICH present in their territory should not be interpreted as intentionally disregarding its existence beyond their borders ${ }^{115}$. Finally, what is notable is that these positions -at least at the level of the IGC's decisions- and the aforementioned "technical requirement" are linked to the proposals towards the List of ICH in Need of Urgent Safeguarding or the Representative List of the ICH of Humanity. As a result, another grey zone is created regarding the respective issue in case of a nomination for the Register of Good Safeguarding Practices ${ }^{116}$, which requires a more profound analysis.

\subsection{Possible responses for a more effective safeguarding of "shared ICH"}

In light of the above, the question remains: how should international law deal with ICH beyond borders? On the one hand, by arguing solely in favor of international cooperation -which usually happens to serve as panacea- as an answer to the system's defi-

in: B. Ubertazzi, 'The Territorial Condition for the Inscription of Elements on the UNESCO Lists of Intangible Cultural Heritage' in ADELL, N.; BENDIX, R. F. et al. (eds). Between Imagined Communities and Communities of Practice. Göttingen Studies in Cultural Property, v. 8, 2015. p. 111-119.

113 UNESCO, IGC, Decisions, 7th session, Paris, 3-7.12.2012, DECISION 7.COM 11, para. 18

114 UNESCO Convention 2003, art. 11

115 "States Parties are encouraged to demonstrate their concern for and responsibility towards ICH and its safeguarding that goes beyond national borders." in: UNESCO, IGC, Item 10 of the Provisional Agenda: Report of the Subsidiary Body on its work in 2014 and examination of nominations for inscription on the RL of the ICH of Humanity, $9^{\text {th }}$ session, UNESCO Headquarters, 24-28.11.2014, p. 10, para. 33

116 The Operational Directives "encourage the submission of subregional or regional programmes, projects and activities as well as those undertaken jointly by States Parties in geographically discontinuous areas": UNESCO Operational Directives 2018, para. 14; However, no answer is given for the case of a programme, project, activity carried out for the safeguarding of a shared heritage manifestation and in the context of a cross-border community but not by actors that could cooperate with both States concerned; Furthermore, it is characteristic that only one multinational nomination has ever been inscribed on the relevant Register in 2009: 'Safeguarding ICH of Aymara communities in Bolivia, Chile and Peru' by those three States. ciencies, seems insufficient and hasn't led to effective protection at least until today, but it is always a safe response intending not to query sovereignty in any case. On the other hand, what other possible solutions could properly respond to the aforementioned in terms of international law and beyond the UNESCO mechanism for ICH? The following analysis will necessarily touch upon two of them, which seem to satisfy -even at a theoretical yet level- in a more complete way the gaps already addressed.

One opinion suggests the perception of ICH as "common heritage of mankind"117, highlighting its transnational character and trying to cope with the current tendency to restrictively define it in terms of contemporary national borders. This presupposes the examination of the diachronically opposite schools of thought of "cultural nationalism" and "cultural internationalism"118. According to them, the first accords a special interest to the State for the protection of its heritage to which it implies the attribution of national character, independently of its location or ownership, while the second thinks about heritage expressions as components of a common human culture, whatever their origin or present location, independent of property rights or national jurisdiction ${ }^{119}$. Despite the fact that these theories have been mostly examined with reference to cultural objects and the -always topical- issue of their return to their country of origin or in relation to world natural and cultural heritage sites, such a conversation is not deprived of interest when transferred in the field of ICH protection.

Hence, if one could adopt the opinion that the 1972 World Heritage Convention reflects the ethos of cultural internationalism ${ }^{120}$, can we also reasonably argue

117 See the principal characteristics of the notion in: JOYNER, C. Legal implications of the concept of the common heritage of mankind. International \& Comparative Law Quarterly, v. 35, 1986. p. 192

118 For a more thorough analysis see indicatively: MACMILLAN, F. The protection of cultural heritage: common heritage of humankind, national cultural patrimony or private property. Northern Ireland Legal Quarterly, v. 64, n. 3, 2013. p. 351-364; WATKINS, J. Cultural nationalists, internationalists, and "intra-nationalists": who's right and whose right? International Journal of Cultural Property, v. 12, n. 1, 2005. p. 78-94

119 MERRYMAN, J. H. Two ways of thinking about cultural property. The American Journal of International Law, v. 80, n. 4, 1986. p. 831-832.

120 ANGLIN, R. The world heritage list: bridging the cultural property nationalism-internationalism divide. Yale Journal of Law \& the Humanities, v. 20, 2008. p. 250. 
that the 2003 ICH Convention leans towards cultural nationalist ideas? The analysis above under the prism of the existent sovereignty "guarantees" in its safeguarding mechanism would probably lead to a positive answer ${ }^{121}$. Besides, in spite of the theoretical importance of this discussion, the 2003 Convention adopts a clear position on the matter by rejecting any reference to the regulatory object as "common heritage" 122 contrary to previous heritage-related instruments ${ }^{123}$. Contrariwise, States recognize that ICH safeguarding "is of general interest to bumanity" 24 , while declaring "aware of the universal will and the common concern to safeguard" it ${ }^{125}$, something consistent with the characterization of cultural diversity as "common heritage of humanity" by the subsequent 2005 UNESCO Convention ${ }^{126}$.

Another opinion suggests the connection of ICH to human rights protection, thus trying to move beyond the restrictive view of it as linked merely to State territories and emphasizing its strong links to its people, as well as the progressive transition from the notion of "cultural heritage of humanity" towards "cultural heritage of communities, groups and individuals"127. Despite the fact that the relation between the two fields is conceptually apparent given the character of $\mathrm{ICH}$, it is

\footnotetext{
121 See the opinion regarding the 2003 Convention's “excessive focus on sovereignty". LIXINSKI, L., Intangible Cultural Heritage in International Law. Oxford: Oxford University Press, 2013. p. 52

122 See also the relevant debate prior to the adoption of the Convention when it was thought "universality should not be applied to the IH itself but to the justification for its safeguarding" in: UNESCO, Select Drafting Group on the first draft of an international convention for intangible cultural heritage, Final Report, Paris, 20-22.3.2002, Discussion Unit 9, Art. 5, para. 1

123 'Being convinced that damage to cultural property belonging to any people whatsoever means damage to the cultural heritage of all mankind'; UNESCO World Heritage Convention 1972, preamble: 'Considering that parts of the cultural or natural heritage are of outstanding interest and therefore need to be preserved as part of the world heritage of mankind as a whole'; UNESCO Recommendation 1989, preamble: 'Considering that folklore forms part of the universal heritage of humanity'. UNITED NATIONS. Convention for the protection of cultural property in the event of armed conflict. 1954. Availableat:http://www.unesco.org/new/en/culture/themes/ armed-conflict-and-heritage/convention-and-protocols/1954hague-convention/ Accessed on: 20 Aug. 2020.

124 UNESCO Convention 2003, art. 19\$2

125 UNESCO Convention 2003, preamble, para. 6

126 UNESCO Convention on the Protection and Promotion of the Diversity of Cultural Expressions, 20.10.2005 (Paris), preamble: 'Conscious that cultural diversity forms a common heritage of bumanity and should be cherished and preserved for the benefit of all'; Furthermore, 2003 Convention faces ICH "as a mainspring of cultural diversity": UNESCO Convention 2003, preamble, para. 3

127 BLAKE, J. International Cultural Heritage Law. Oxford: Oxford University Press, 2015. p. 272
}

by no means an easy work to overcome a series of theoretical and practical obstacles. While a human rights approach in ICH safeguarding is accepted as necessary ${ }^{128}$, the reverse direction in order to use human rights international protection mechanism for an ultimate $\mathrm{ICH}$ protection is still a controversial issue ${ }^{129}$. The question is, then, posed in this way: could a right to $\mathrm{ICH}$ per se be founded and how could this affect State sovereignty or the present UNESCO mechanism? A detailed examination of the whole human rights system (international and regional) in order to detect the favorable legal bases for establishing such a right and a profound analysis of their content would go beyond the scope of the present paper. Therefore, some only preliminary observations will be made as follows.

Firstly, one could seek an indirect protection in using established human rights beyond those numbered among cultural rights ${ }^{130}$, since the ultimate aim is to protect ICH bearers, let alone human dignity and identity ${ }^{131}$. Besides, respecting human rights seems a sine qua non condition for effectively safeguarding this aspect of heritage which is indissolubly connected to its people and presupposes also the protection of the circumstances, structures and processes permitting its creation, maintenance and transmission ${ }^{132}$, even if that means

$\overline{128}$ A reference to the existing international human rights instruments exists in the preamble of the 2003 Convention (para. 2); One aspect of this approach is also the following provision: UNESCO Convention 2003, art. 2\$1: "For the purposes of this Convention, consideration will be given solely to such ICH as is compatible with existing international buman rights instruments".

129 Besides, the relevance between the two fields is not always taken for granted at an international level: BENNOUNE, K. Special rapporteur in the field of cultural rights. 2017. Availableat:https://www.ohchr. org/en/issues/culturalrights/pages/srculturalrightsindex.aspx Accessed on: 20 Aug. 2020. p. 6.

130 It has been supported that such rights could be inter alia: the right to freedom of expression, thought, conscience and religion, property ownership, protection of private and family life, information and education. Most importantly: the right of members of minorities in community with the other members of their group to enjoy their own culture, to profess and practice their own religion, or to use their own language, as well as the right of indigenous peoples to self-determination and to maintain, control, protect and develop their cultural heritage.

131 K. S. Ziegler, 'Cultural Heritage and Human Rights' in ALBERICO Gentili: la salvaguardia dei beni culturali nel diritto internazionale. Milano: Giuffrè, 2008.

132 According to one opinion, protecting the 'practitioners' themselves is more important than generally safeguarding ICH: BAKAR, A. A. et al. Analysis on Community Involvement Level in Intangible Cultural Heritage: Malacca cultural community. Procedia - Social and Behavioral Sciences, v. 153, 2014. p. 287. 
protecting their ways of life and their cultural identity ${ }^{133}$. However, using cultural rights as a basis might prove more effective, especially taking into consideration the latest developments towards their expansive and progressive interpretation so as to include also the dimension of cultural heritage protection. Thus, an expanded interpretation of the right to participate in cultural life ${ }^{134}$ containing in its scope the right of access to and enjoyment of cultural heritage is already made at the level of UN Human Rights Council (hereafter HRC) ${ }^{135}$. The latter has appointed an independent expert in the field of cultural rights, who interestingly concludes in her thematic report adopted by it, that safeguarding cultural heritage is a human rights issue and that the right to (access and enjoyment of) it finds its legal basis in the right to take part in cultural life ${ }^{136}$, something later also stated by the HRC "calling upon all States to respect, promote and protect" this right ${ }^{137}$. Furthermore, the interpretation of the same right by the Committee on Economic Social and Cultural Rights in its General Comment No. $21^{138}$ so as to incorporate the cultural heritage dimension -referring to ICH as well- is consistent with the system's reasoning.

Secondly, even if we can arguably use the aforementioned or other human rights as legal basis, there are still some objections that cannot be easily rebutted. On

133 LIXINSKI, L., Intangible Cultural Heritage in International Lam Oxford: Oxford University Press, 2013. p. 145

134 UNITED NATIONS. Universal Declaration of Human Rights. Availableat: https://www.un.org/en/universal-declaration-humanrights/ Accessed on: 20 Aug. 2020. Everyone has the right freely to participate in the cultural life of the community [...]'; UNITED NATIONS. International Covenant on Economic, Social and Cultural Rights. 1966. Availableat: https://www.ohchr.org/EN/ProfessionalInterest/Pages/CESCR.aspx Accessed on: 20 Aug. 2020. ' ... the right of everyone: (a) To take part in cultural life [...]'

135 See an analysis of how HRC deals with cultural rights RICHARDSON, L. Economic, social and cultural rights (and beyond) in the UN human rights council. Human Rights Law Review, v. 15, p. 409-440, 2015.

136 HRC, Agenda item 3-Report of the independent expert in the field of cultural rights. SHAHEED, Farida. Report of the independent expert in the field of cultural rights. New York: UN Human Rights Council, 2011.

137 HRC, Resolution 33/20: Agenda item 3-Cultural rights and the protection of cultural heritage, $33^{\text {rd }}$ Session, 27.9.2016, preamble: paras. 4-5 and para. 1

138 UN COMMITTEE ON ECONOMIC, SOCIAL AND CULTURAL RIGHTS. General comment No. 21: Right of everyone to take part in cultural life (art. 15, para. 1 (a), of the ICESCR), $43^{\text {rd }}$ Session. 2009. Availableat:https://www.refworld.org/docid/4ed35bae2.html Accessed on: 20 Aug. 2020; Nonetheless, the Committee has never proceeded with adopting views in a case examining art. 15 para. 1a and as a result no practical example of the application of this interpretation exists so far. the one hand, seeking protection through a mechanism founded on the individual for a -par excellence- collectively defined heritage seems paradoxical. However, the following parameters should be taken into consideration. First, ICH notion contains a human dimension ${ }^{139}$, even an individualized one, insofar as every single community member is hypothetically a "bearer" of ICH manifestations. Second, some of the proposed rights are characterized by a collective dimension, even if they are typically individual, as is mainly the case of cultural rights, since culture and cultural life -alike heritage- entail a direct reference to a form of collectivity ${ }^{140}$. Third, an explicit tendency towards the recognition of collective rights is noticed in human rights field ${ }^{141}$, principally in relation to minorities and indigenous peoples but beyond this context as well ${ }^{142}$. In particular, it is noteworthy that especially regarding indigenous peoples -even yet in soft law instruments- a reference is made to their collective right to $\mathrm{ICH}^{143}$ as well as to some aspects of the protection of cross-border indigenous communities $^{144}$.

On the other hand, even if we could compromise with the individual or collective nature of the rights, a range of other legal questions immediately arise. Who could be specified as the subject of protection ${ }^{145}$ ? If we accept that ICH bearers ${ }^{146}$ as those creating, maintaining and trans-

139 FRANCIONI, F. The human dimension of international cultural heritage law: an introduction. The European Journal of International Law, v. 22, n. 1, 2011. p. 9-16.

140 CHOW, P. Y. S. Culture as collective memories: an emerging concept in international law and discourse on cultural rights. Human Rights Law Review, v. 14, 2014. p. 611-646.

141 See more on this topic in: MORANTZ, T. Individual rights versus collective rights: the debate on the aboriginal peoples of Canada. Sociological Bulletin, Indian Sociological Society, v. 46, n. 2, 1997

142 JOVANOVIC, M. A. Recognizing minority identities through collective rights. Human Rights Quarterly, v. 27, n. 2, 2005. p. 625-651; The jurisprudence of the Inter-American Court of Human Rights features a very interesting approach to the recognition of collective rights and forms of collective reparation.

143 ORGANIZATION OF AMERICAN STATES. American Declaration on the Rights of Indigenous Peoples. 2016. Available at: https:// www.culturalsurvival.org/sites/default/files/media/2016oas-declaration-indigenous-people.pdf Accessed on: 20 Aug. 2020.

144 United Nations Declaration 2007, art. 36

145 See an analysis on those who are typically recognized as beneficiaries of collective human rights in the international system, namely peoples, minorities and indigenous peoples, in: JOVANOVIĆ, M. A. Are there universal collective rights? Human Rights Review, v. 11, 2008. p. 17

146 Interesting definitions on communities, groups and individuals are found in: UNESCO, Expert meeting on Community Involvement in Safeguarding ICH, Final Report, Tokyo, Japan, 13-15.3.2006, p. $12-13$ 
mitting it should in principal be the beneficiaries, could we respectively talk about an "ICH community" could it be defined ${ }^{148}$ ? How could the whole conversation regarding ICH safeguarding and territories be "transferred" in the international human rights system in order to keep up with its own requirements? Most importantly, what are the implications of associating the territorial condition for ICH safeguarding and the obligation of the State under human rights law to respect and ensure the rights of individuals subject to its jurisdiction ${ }^{149}$ ?

Finally, a -more moderate but maybe more effectiveresponse to all the aforementioned deficiencies could have as a point of departure the exactly reversed question, namely: how could the debate on human rights protection as a means for ultimately safeguarding ICH, protecting its bearers and their relationship with it, through the establishment of a right to $\mathrm{ICH}$, be "transplanted" into the UNESCO mechanism and with what cost? Interestingly, the IGC adopted in 2015 twelve Ethical Principles for ICH Safeguarding, following an expert meeting report, among which Principle 2 declares: 'the right of communities, groups and individuals to continue the practices, representations, expressions, knowledge and skills necessary to ensure the viability of the ICH ${ }^{150}$. Although those Principles -contained in a soft-law, thus non-binding, instrument- function merely as a code of conduct, their adoption shows the position of -at least some of- the States Parties and reveals the existence of a dynamic tension of contemporary inter-State discussion towards the recognition of a right to $\mathrm{ICH}^{151}$.

\footnotetext{
147 UNESCO Convention 2003 does not contain a definition of "community". We find the definition of "heritage community" for the first time in: COUNCIL OF EUROPE. Convention on the Value of Cultural Heritage for Society. 2005. Availableat:https://www.coe.int/en/web/ culture-and-heritage/faro-convention Accessed on: 20 Aug. 2020.

148 See a comparative analysis on the "heritage community" of the Faro Convention and the "communities, groups and individuals" of the ICH Convention in: L. Zagato, "The Notion of "Heritage Community" in the Council of Europe's Faro Convention. Its Impact on the European Legal Framework' in ADELL, N.; BENDIX, R. F. et al. (eds). Between Imagined Communities and Communities of Practice. Göttingen Studies in Cultural Property, v. 8, 2015. p. 153-160.

149 See an analysis on the notion of jurisdiction, its use in international human rights instruments and its relation to territory. SICILIANOS, L. A. (ed.). European convention on buman rights: interpretation by article. Athens: Nomiki Bibliothiki, 2013. Another under-explored dimension of this issue is the extra-territorial application of human rights.

150 UNESCO, Ethical Principles for Safeguarding ICH 2015, Principle 2; UNESCO, IGC, Decisions, 10th session, Windhoek, Namibia 30.11-4.12.2015, DECISION 10.COM 15.a, Annex

151 This recognition seems to go beyond the conventional one on
}

Therefore, under the prism of this evolutionary human rights approach and the first ever recognition within UNESCO of an -individual and collective- right to $\mathrm{ICH}$, even of an aspirational rather than prescriptive nature ${ }^{152}$, the demand for a more active participation of communities, groups and individuals in the implementation of the safeguarding mechanism comes up once again ${ }^{153}$. In this framework, the establishment of a right to ICH does not seem unrealistic, though yet premature. Possible measures, however, towards the effective expansion of community participation, and on the basis of their right under-recognition, would presuppose the initiation of new protection tools in their hands? On the one hand, a provision for the possibility of communities to submit their own nominations for elements inscriptions on national inventories and UNESCO Lists, on the basis of the proved special links to them and independent of the State to the jurisdiction of which they are subject or the prerequisite of ICH presence in a territory, would probably give a solution to the effective safeguarding of shared ICH. On the other hand, the recognition of the IGC's capacity to receive individual or collective complaints on the basis of the recognition of a right to ICH and claims of its violation by a State Party, borrowing the tools from human rights international protection model, would probably translate into a true implementation of that right. At the end of the day, the IGC would still reserve the power of the final decisions.

\section{Conclusion. Transcending borders through Intangible Cultural Heritage?}

The present analysis examined the existent safeguarding mechanism for $\mathrm{ICH}$ as established by the 2003 UNESCO Convention through the lens of its

the measures that should be adopted by States in order to ensure access to ICH: UNESCO Convention 2003, art. 13(d-ii); Besides, the latter is reflected in Ethical Principle 5.

152 UNESCO, Expert meeting on a model code of ethics for ICH, Towards codes of ethics for ICH?, Valencia, Spain, 30.3-1.4.2015, para. 23,30

153 According to one opinion, the Operational Directives have begun to move in the direction of a more effective community involvement by concretizing some particular aspects of it: BLAKE, J. International Cultural Heritage Law. Oxford: Oxford University Press, 2015. p. 186; But at the same time no relevant guarantees exist especially at the international level where the State-centric approach clearly prevails: LIXINSKI, L., Intangible Cultural Heritage in International Law. Oxford: Oxford University Press, 2013. p. 55 
underlying "guarantees" for respecting sovereignty. The system's particular concern to deal with heritage manifestations that "may easily escape the territorial jurisdiction of the State" 154 , let alone "shared" heritage, traverses the whole ICH safeguarding regime. In terms of international law whose principal subject is the State and especially in the politically sensitive field of cultural heritage, a State-oriented approach might seem reasonable. However, the parameter of the human dimension of ICH protection shows the direction towards the need for a more community-oriented approach instead.

ICH intrinsically raises the question of limits ${ }^{155}$, either if that means the limits between different areas of law and the figurative frontiers raised between all actors involved in its safeguarding or the real inter-State borders. Safeguarding ICH seems challenging, insofar as the demand for a more active role of its communities in the system, as well as the recognition of its transboundary character, enter into the dialogue. ICH finds itself in a constant movement in a contemporary world where any approach to deal with its transboundary manifestations would necessarily go beyond their static version and proceed with highlighting ICH's constant "flows" even in their "cross-border" dimension. Ever-growing migration and refugee flows should add a new parameter to the whole conversation. International law cannot remain indifferent to the dynamics of ICH within the State and beyond contemporary States.

The institutionalization of this well-criticized term and the mechanism founded on it may have led to build "intangible borders" in areas where they were never supposed to exist. Thus, could international law tools contribute to bridge those artificially established boundaries, as a result of the application of the "territorial presence" condition in the case of $\mathrm{ICH}$, or on the contrary will they serve in perpetuating them? In this context, recognizing humanity's common concern to safeguard ICH is of great importance, while as a step further, favorable conditions for the establishment of an -individual or even collective- right to ICH are being shaped.

The field of ICH international protection is par excellence a dynamic one and thus open to creativity

\footnotetext{
154 LIXINSKI, L., Intangible Cultural Heritage in International Law. Oxford: Oxford University Press, 2013. p. 22.

155 DUBE, P. The Beauty of the Living. Museum International, V. 56, n. 1-2, 2004. p. 123
}

and new contributions within a process of evolution and transformation. But, how could it adapt to those challenges? Paraphrasing the famous doctrine, are States "unable" to move beyond the existent narrow legal framework or "unwilling" to let this form of cultural heritage shake the foundations of their sovereignty construction? The writer would suggest that the current phase of evolution of the international law for the safeguarding of $\mathrm{ICH}$, following a consistent -more than decennial- application of the 2003 UNESCO Convention after its entry into force in 2006, maybe needs more a re-orientation and re-position of the main crucial questions at stake, rather than absolute answers to the already apparent deficiencies. So, let's go back to the beginning and pose a fundamental question: should we deal with ICH as peoples' heritage or States' heritage?

\section{References}

ADELL, N.; BENDIX, R. F. et al. (eds). Between Imagined Communities and Communities of Practice. Göttingen Studies in Cultural Property, v. 8, 2015.

ALBERICO Gentili: la salvaguardia dei beni culturali nel diritto internazionale. Milano: Giuffrè, 2008.

ANDERSON, B. Imagined communities: reflections on the origin and spread of nationalism. London, New York: Verso, 2006.

ANGLIN, R. The world heritage list: bridging the cultural property nationalism-internationalism divide. Yale Journal of Law \& the Humanities, v. 20, 2008.

ARIZPE, L.; AMESCUA, C. (ed.). Anthropologicalperspectives on intangible cultural heritage. London: Springer, 2013.

AYKAN, B. Patenting Karagöz: UNESCO, nationalism and multinational intangible heritage. International Journal of Heritage Studies, v. 21, n. 10, 2015.

BAKAR, A. A. et al. Analysis on Community Involvement Level in Intangible Cultural Heritage: Malacca cultural community. Procedia - Social and Behavioral Sciences, v. 153, 2014.

BEN SHE. Law of the people's republic of china on intangible cultural heritage. New York: Law Press, 2011.

BENNOUNE, K. Special rapporteur in the field of cultural rights. 2017. Available at: https://www.ohchr.org/en/ issues/culturalrights/pages/srculturalrightsindex.aspx 
Accessed on: 20 Aug. 2020.

BLAKE, J. Commentary on the 2003 UNESCO Convention on the Safeguarding of the Intangible Cultural Heritage. New York: Institute of Art and Law, 2006.

BLAKE, J. International Cultural Heritage Law. Oxford: Oxford University Press, 2015.

BLAKE, J. Introduction to the draft preliminary study into the advisability of developing a new standard-setting instrument for the safeguarding of intangible cultural heritage. 2001. Available at: https://ich.unesco.org/doc/src/05358-EN.pdf Accessed on: 20 Aug. 2020.

CHOW, P. Y. S. Culture as collective memories: an emerging concept in international law and discourse on cultural rights. Human Rights Law Review, v. 14, 2014.

COUNCIL OF EUROPE. Convention on the Value of Cultural Heritage for Society. 2005. Available at: https:// www.coe.int/en/web/culture-and-heritage/faro-convention Accessed on: 20 Aug. 2020.

DUBE, P. The Beauty of the Living. Museum International, V. 56, n. 1-2, 2004.

EAGEN, S. Preserving cultural property: our public duty: a look at how and why we must create international laws that support international action. Pace International Law Review, v. 13, n. 2, 2001.

FORREST, C. International Law and the Protection of Cultural Heritage. United Kingdom: Routledge, 2010.

FRANCIONI, F. Beyond state sovereignty: the protection of cultural heritage as a shared interest of humanity. Michigan Journal of International Law, v. 25, 2004.

FRANCIONI, F. The human dimension of international cultural heritage law: an introduction. The European Journal of International Law, v. 22, n. 1, 2011.

FRANCIONI, F.; GORDLEY, J. (eds.). Enforcing international cultural heritage law. Oxford: Oxford University Press, 2013.

FRASER, J. Cultural heritage in transit: intangible rights as human rights ed. By Deborah Kapcha (review). Human Riguts Quartely, v. 37, n. 2, 2015.

HUMAN RIGHTS COUNCIL. Resolution adopted by the Human Rights Council on 30 September 2016. Available at: https://www.right-docs.org/doc/a-hrc-res-33-20/ Accessed on: 20 Aug. 2020.

JOVANOVIĆ, M. A. Are there universal collective rights? Human Rights Review, v. 11, 2008.

JOVANOVIC, M. A. Recognizing minority identities through collective rights. Human Rights Quarterly, v. 27, n. 2, 2005.

JOYNER, C. Legal implications of the concept of the common heritage of mankind. International \& Comparative Law Quarterly, v. 35, 1986.

KURIN, R. Safeguarding intangible cultural heritage in the 2003 UNESCO Convention: a critical appraisal. Museum International, v. 56, n. 1-2, 2004.

KURIN, R. Safeguarding intangible cultural heritage: key factors in implementing the 2003 convention. International Journal of Intangible Heritage, v. 2, p. 9-20, 2007.

KURUK, P. Cultural heritage, traditional knowledge and indigenous rights: an analysis of the convention for the safeguarding of intangible cultural heritage. Macquarie Journal of International and Comparative Environmental Law, v. 1, 2004.

LANKARANI, L. L'avant-projet de convention de l'Unesco pour la sauvegarde du patrimoine culturel immatériel: évolution et interrogations. Annuaire français de droit international, v. 48, 2002.

LAW of the republic of indonesia: number 19 year 2002. Available at: http://cipatent.com/pdf/copyrightslaw.pdf Accessed on: 20 Aug. 2020.

LENZERINI, F. Intangible cultural heritage: the living culture of peoples. The European Journal of International Law, v. 22, n. 1, 2011.

LIXINSKI, L. Between orthodoxy and heterodoxy: the troubled relationships between heritage studies and heritage law. International Journal of Heritage Studies, v. 21, n. 3, 2015.

LIXINSKI, L. et al. Identity beyond borders: international cultural heritage law and the temple of preah vihear dispute. ILSA Quarterly, v. 20, n. 1, 2011.

LIXINSKI, L. Selecting heritage: the interplay of art, politics and identity. European Journal of International Law, v. 22, 2011.

LIXINSKI, L., Intangible Cultural Heritage in International Law. Oxford: Oxford University Press, 2013.

LOGAN, W. Cultural diversity, cultural heritage and human rights: towards heritage management as human rights-based cultural practice. International Journal of He- 
ritage Studies, v. 18, n. 3, 2012.

MACMILLAN, F. The protection of cultural heritage: common heritage of humankind, national cultural patrimony or private property. Northern Ireland Legal Quarterly, v. 64, n. 3, 2013.

MERRYMAN, J. H. Two ways of thinking about cultural property. The American Journal of International Law, v. 80, n. 4, 1986.

MORANTZ, T. Individual rights versus collective rights: the debate on the aboriginal peoples of Canada. Sociological Bulletin, Indian Sociological Society, v. 46, n. 2, 1997.

NETTLEFORD, R. Migration, transmission and maintenance of the intangible heritage. Museum International, v. 56, n. 1-2, 2004.

NIEC, H. (ed.). Cultural Rights and Wrongs. Paris: UNESCO, 1998.

ORGANIZATION OF AMERICAN STATES. American Declaration on the Rights of Indigenous Peoples. 2016. Available at: https://www.culturalsurvival.org/sites/ default/files/media/2016oas-declaration-indigenouspeople.pdf Accessed on: 20 Aug. 2020.

POULIOS, I. (ed). Cultural management, local society and sustainable development(in greek). Athens: Hellenic Academic Libraries Link, 2015.

PROTT, L. V.; O'KEEFE, P. J. Cultural heritage or cultural property? International Journal of Cultural Property, v. 1, 1992.

RICHARDSON, L. Economic, social and cultural rights (and beyond) in the UN human rights council. Human Rights Law Review, v. 15, 2015.

SCHMITT, T. M. The UNESCO concept of safeguarding intangible cultural heritage: its background and marrakchi roots. International Journal of Heritage Studies, v. 14, n. 2, 2008.

SCHUSTER, J. M. Making a list and checking it twice: the list as a tool of historic preservation. 2002. Available at: https://ideas.repec.org/p/har/wpaper/0303.html Accessed on: 20 Aug. 2020.

SHAHEED, Farida. Report of the independent expert in the field of cultural rights. New York: UN Human Rights Council, 2011.

SICILIANOS, L. A. (ed.). European convention on buman rights: interpretation by article. Athens: Nomiki Bibliothiki, 2013.

SMITH, L.; AKAGAWA, N. (ed.). Intangible heritage. Abingdon, United Kingdom: Routledge, 2009.

STEFANO, M. L.; DAVIS, P. (ed.). The Routledge Companion to intangible cultural heritage. Abingdon, United Kingdom: Routledge, 2017.

UN COMMITTEE ON ECONOMIC, SOCIAL AND CULTURAL RIGHTS. General comment No. 21: Right of everyone to take part in cultural life (art. 15, para. 1 (a), of the ICESCR), $43^{\text {rd }}$ Session. 2009. Available at: https://www.refworld.org/docid/4ed35bae2. html Accessed on: 20 Aug. 2020.

UNESCO ICH Section, Aide-mémoire for completing a nomination to the RL of the ICH of Humanity for 2016 and later nominations, 02.2015

UNESCO Recommendation on the Safeguarding of Traditional Culture and Folklore, 15.11.1989 (Paris)

UNESCO, Expert meeting on a model code of ethics for ICH, Towards codes of ethics for ICH?, Valencia, Spain, 30.3-1.4.2015

UNESCO, Expert meeting on Community Involvement in Safeguarding ICH, Final Report, Tokyo, Japan, 13-15.3.2006

UNESCO, Expert meeting on documentation and archiving of ICH, Meeting Report, Paris, France, 1213.1.2006

UNESCO, Expert Meeting on the Lists Established in the 2003 Convention for the Safeguarding of the Intangible Cultural Heritage, Summary report of the meeting, New Delhi, India, 2-4.4.2007

UNESCO, First meeting of the select drafting group of a preliminary international convention on ICH, Final Report, Paris, 20-22.3.2002

UNESCO, IGC, Decisions, 6th session, Bali, Indonesia, 22-29.11.2011, DECISION 6.COM 13

UNESCO, IGC, Decisions, 7th session, Paris, 3-7.12.2012, DECISION 7.COM 11

UNESCO, IGC, Decisions, 7th session, UNESCO Headquarters, Paris, 3-7.12.2012, DECISION 7.COM 14

UNESCO, IGC, Decisions, 9th session, Paris, 2428.11.2014, DECISION 9.COM 11

UNESCO, IGC, Item 10 of the Provisional Agenda: Report 
of the Subsidiary Body on its work in 2014 and examination of nominations for inscription on the RL of the ICH of Humanity, $9^{\text {th }}$ session, UNESCO Headquarters, 24-28.11.2014

UNESCO, IGC, Item 14 of the Provisional Agenda: Mechanism for sharing information to encourage multinational nominations, 7th session, UNESCO Headquarters, Paris, 3-7.12.2012

UNESCO, IGC, Item 4 of the Provisional Agenda: Adoption of the summary records of the eighth session of the Committee, $9^{\text {th }}$ Session, 24-28.11.2014

UNESCO, IGC, Item 7 of the Provisional Agenda: Report of the Consultative Body on its work in 2011, $6^{\text {th }}$ Session, Bali, Indonesia, 22-29.11.2011

UNESCO, IGC, Item 8 of the Provisional Agenda: Evaluation of nominations for inscription in 2011 on the List of ICH in Need of Urgent Safeguarding, $6^{\text {th }}$ Session, Bali, Indonesia, 22-29.11.2011

UNESCO, IGC, Report of the Rapporteur of the subsidiary body on the modalities for the participation of communities or their representatives, practitioners, experts, centres of expertise and research institutes in the implementation of the Convention, $2^{\text {nd }}$ Extraordinary Session, Sofia, Bulgaria, 18-22.2.2008

UNESCO, Intangible Heritage Beyond Borders: Safeguarding Through International Cooperation-Regional Meeting, Background paper, Bangkok (Thailand), 2021.7.2010

UNESCO, Intergovernmental Meeting of Experts on the Preliminary Draft Convention for the Safeguarding of the ICH, Compilation of amendments from Member States concerning the Convention for the Safeguarding of the $\mathrm{ICH}, 2^{\text {nd }}$ Session, Paris, 24.2-1.3.2003

UNESCO, Intergovernmental Meeting of Experts on the Preliminary Draft Convention for the Safeguarding of ICH, Position des Etats Membres eu egard au principe de liste(s) du patrimoine culturel immaterial-7 Octobre 2002, $2^{\text {nd }}$ Session, Paris, 24.2- 1.3.2003

UNESCO, Intersessional Working Group of government experts on the Preliminary Draft Convention for the Safeguarding of the ICH, Report by Pr. C. Economides, Paris, 22-30.4.2003

UNESCO, Meeting of the "Restricted Drafting Group", Preparation of a preliminary draft International Convention on the ICH, Paris, 20-22.3.2002

UNESCO, Operational Directives for the Implementation of the Convention for the Safeguarding of the Intangible Cultural Heritage, 2.GA, Paris, 16-19.6.2008, as amended into their last version (2018)

UNESCO, Select Drafting Group on the first draft of an international convention for intangible cultural heritage, Final Report, Paris, 20-22.3.2002

UNESCO. Convention concerning the protection of the world cultural and natural heritage. Available at: https://whc. unesco.org/en/conventiontext/ Accessed on: 20 Aug. 2020.

UNESCO. Convention for the safeguarding of the intangible cultural heritage. Available at: https://ich.unesco.org/ doc/src/15164-EN.pdf Accessed on: 20 Aug. 2020.

UNESCO. Convention on the protection and promotion of the diversity of cultural expressions. Available at: https:/ / en.unesco.org/creativity/convention Accessed on: 20 Aug. 2020.

UNESCO. Convention on the protection of the underwater cultural heritage. Available at: http://www.unesco. org/new/en/culture/themes/underwater-culturalheritage/2001-convention. Accessed on: 20 Aug. 2020.

UNESCO. Declaration concerning the intentional destruction of cultural heritage. Available at: http://portal.unesco. org/en/ev.php-URL_ID =17718\&URL_DO=DO_ TOPIC\&URL_SECTION=201.html Accessed on: 20 Aug. 2020.

UNESCO. Ethical Principles for Safeguarding Intangible Cultural Heritage. Available at: https://ich.unesco.org/en/ ethics-and-ich-00866 Accessed on: 20 Aug. 2020.

UNESCO. Executive Board, Report on the preliminary study on the advisability of regulating internationally, through a new standard-setting instrument, the protection of Traditional Culture and Folk.lore, $161^{\text {st }}$ session, Paris, 28.5-13.6.2001

UNESCO. Implementing the Convention for the Safeguarding of the ICH. Available at: https://ich.unesco.org/doc/ src/01853-EN.pdf Accessed on: 20 Aug. 2020.

UNESCO. Masterpieces of the oral and intangible heritage of bumanity Available at: https://www.britannica.com/to$\mathrm{pic} /$ Masterpieces-of-Oral-and-Intangible-Heritage-ofHumanity Accessed on: 20 Aug. 2020.

UNESCO. Questions and answers about intangible cultural heritage. Available at: https://docplayer.net/133185893Questions-answers-intangible-cultural-heritage.html Accessed on: 20 Aug. 2020. 
UNESCO. Second Protocol to the Hague Convention of 1954 for the Protection of Cultural Property in the Event of Armed Conflict 1999. Available at: bttp://portal.unesco. org/en/ev.php-URL_ID $=15207 \nLeftarrow U R L \_D O=D O \_$ TOPIC\&URL_SECTION=201.html Accessed on: 20 Aug. 2020.

UNESCO. Universal Declaration on Cultural Diversity. Available at: http://orcp.hustoj.com/unesco-universaldeclaration-on-cultural-diversity-2001 Accessed on: 20 Aug. 2020.

UNITED NATIONS. Convention for the protection of cultural property in the event of armed conflict. 1954. Available at: http://www.unesco.org/new/en/culture/ themes/armed-conflict-and-heritage/convention-andprotocols/1954-hague-convention/ Accessed on: 20 Aug. 2020.

UNITED NATIONS. Declaration on the Rights of Indigenous Peoples. Available at: https://www.ohchr.org/en/ issues/ipeoples/pages/declaration.aspx Accessed on: 20 Aug. 2020.

UNITED NATIONS. International Covenant on Economic, Social and Cultural Rights. 1966. Available at: https:// www.ohchr.org/EN/ProfessionalInterest/Pages/CESCR.aspx Accessed on: 20 Aug. 2020.
UNITED NATIONS. Universal Declaration of Human Rights. Available at: https://www.un.org/en/universaldeclaration-human-rights/ Accessed on: 20 Aug. 2020.

VAN ZANTEN, W. Constructing new terminology for intangible cultural heritage. Museum International, v. 56, n. 1-2, 2004.

VECCO, M. A definition of cultural heritage: from the tangible to the intangible. Journal of Cultural Heritage, v. 11, 2010.

VERNON, M. C.Common cultural property: the search for rights of protective intervention. Case Western Reserve Journal of International Law, v. 26, n. 2, 1994.

WATKINS, J. Cultural nationalists, internationalists, and "intra-nationalists": who's right and whose right? International Journal of Cultural Property, v. 12, n. 1, 2005.

WIPO. The protection of traditional cultural draft articles. 2018. Available at: https://www.wipo.int/meetings/ en/doc_details.jsp?doc_id=expressions: 409623 Accessed on: 20 Aug. 2020. 
Para publicar na Revista de Direito Internacional, acesse o endereço eletrônico www.rdi.uniceub.br ou www.brazilianjournal.org.

Observe as normas de publicação, para facilitar e agilizar o trabalho de edição. 